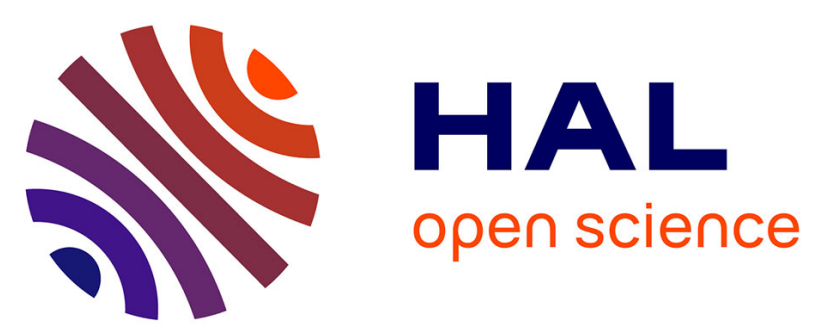

\title{
Uranyl sorption onto birnessite: A surface complexation modeling and EXAFS study
}

Sophie Rihs, Clotilde Gaillard, Tobias Reich, Stephan Kohler

\section{To cite this version:}

Sophie Rihs, Clotilde Gaillard, Tobias Reich, Stephan Kohler. Uranyl sorption onto birnessite: A surface complexation modeling and EXAFS study. Chemical Geology, 2014, 373, pp.59-70. 10.1016/j.chemgeo.2014.02.025 . in2p3-00980434

\section{HAL Id: in2p3-00980434 https://hal.in2p3.fr/in2p3-00980434}

Submitted on 12 Oct 2021

HAL is a multi-disciplinary open access archive for the deposit and dissemination of scientific research documents, whether they are published or not. The documents may come from teaching and research institutions in France or abroad, or from public or private research centers.
L'archive ouverte pluridisciplinaire HAL, est destinée au dépôt et à la diffusion de documents scientifiques de niveau recherche, publiés ou non, émanant des établissements d'enseignement et de recherche français ou étrangers, des laboratoires publics ou privés.

\section{(ㅇ)(1) $\$$}

Distributed under a Creative Commons Attribution - NonCommerciall 4.0 International 


\title{
Uranyl sorption onto birnessite: A surface complexation modeling and EXAFS study
}

\author{
Sophie Rihs ${ }^{\mathrm{a}, *}$, Clotilde Gaillard ${ }^{\mathrm{b}}$, Tobias Reich ${ }^{\mathrm{c}}$, Stephan J. Kohler ${ }^{\mathrm{d}}$ \\ a Laboratoire d'Hydrologie et de Géochimie de Strasbourg, EOST, Université de Strasbourg and CNRS, 1 rue Blessig, 67084 Strasbourg cedex, France \\ b Institut de Physique Nucléaire de Lyon, CNRS/IN2P3-Université de Lyon, 4 rue Enrico Fermi, 69622 Villeurbanne cedex, France \\ c Johannes Gutenberg-Universität Mainz, Institute of Nuclear Chemistry, Fritz-Strassmann-Weg 2, 55128 Mainz, Germany \\ d Department of Aquatic Sciences and Assessment, Swedish University of Agricultural Sciences, P.O. Box 7050, SE-750 07 Uppsala, Sweden
}

This work investigates the mechanism of the uranyl interaction with birnessite, one of the most common layertype $\mathrm{MnO}_{2}$ mineral at the Earth's surface, by coupling macroscopic (surface complexation experiments) and microscopic (EXAFS measurements) approaches. The sorption of uranyl on synthetic hexagonal birnessite, the low$\mathrm{pH}$ birnessite form, was studied under various conditions of $\mathrm{pH}(3-6)$, electrolyte backgrounds $\left(0.1 \mathrm{M} \mathrm{NaClO}_{4}\right.$, $\mathrm{NaNO}_{3}$ and $\mathrm{Na}_{2} \mathrm{CO}_{3}$ ), and solid/liquid ratios (from 0.27 to $4.5 \mathrm{~g} / \mathrm{L}$ ). Sorption isotherms exhibit a complex form indicative of at least two types of sorption sites. EXAFS data reveal the presence of two equatorial 0 shells at ca. 2.32 A and $2.46 \AA$ for all the samples, and a Mn shell at ca. $3.38 \AA$ in the low-pH $(\leq 5)$ samples only. No U-U pair was detected, despite the presence of polynuclear dissolved species in some of the samples.

From the combination of the sorption isotherms and EXAFS results, a structural model for the sorption of uranyl onto hexagonal birnessite is proposed, in which two energetically different sites are involved. At low $\mathrm{pH}(\leq 5)$ a bidentate edge-sharing complex with Mn octahedra of the mineral edges can be inferred, whereas bidentate corner-sharing and/or monodentate complexation to layer vacancies would most likely describe EXAFS features of higher $\mathrm{pH}$ samples. A diffuse double layer model of surface complexation was developed for describing within the same framework the uranyl sorption against $\mathrm{pH}$, involving both high-affinity (Mn octahedra edge) and lowaffinity (above layer vacancies) sites.

The comparison of the uranyl sorption onto hexagonal birnessite and various related environmental minerals shows that the affinity of uranyl for birnessite largely exceeds the sorption observed on montmorillonite and zeolite and turns out to be comparable to iron oxides, confirming the potential role of phyllomanganates to the control of uranyl mobility in post-oxic acidic environments.

\section{Introduction}

Mineral weathering and anthropogenic contamination release uranium in natural systems. Apart from the toxicological threat that this radionuclide presents to living organisms, the understanding of $\mathrm{U}$ mobility in the environment is also a key parameter for fundamental issues, because this element is a tool widely used via its decay-chain to quantify miscellaneous quaternary processes, such as climate change, magmatic activity, global chemical transfer from continents to oceans, weathering rates and pedogenic processes (e.g., reviews from Bourdon et al. (2003), Ivanovich and Harmon (1992)). Most of these applications imply to date either the formation of supergene minerals (carbonates, clays or Fe-Mn oxides) or the weathering of primary magmatic minerals. Accordingly the extent to which these phases are able to remain close to further

\footnotetext{
* Corresponding author. Tel.: + 33368850372.

E-mail addresses: rihs@unistra.fr (S. Rihs), c.gaillard@ipnl.in2p3.fr (C. Gaillard), treich@uni-mainz.de (T. Reich), Stephan.Kohler@slu.se (S.J. Kohler).
}

isotopic re-equilibration, depending on the crystallographic site of $U$ incorporation, is of fundamental interest.

In supergene formations, the dominating control of $U$ mobility by iron oxides was largely reported, with enrichment factors in these oxides several orders of magnitude higher than of zeolites, silica gel and clays (Langmuir, 1978; Ames et al., 1983; Payne et al., 1998; Gustafsson et al., 2009). In contrast, specific studies of U-Mn oxides interaction are scarce (Al-Attar and Dyer, 2002; Fredrickson et al., 2002; Webb et al., 2006; Brennecka et al., 2011; Wang et al, 2013), while the prevailing role of Mn-oxides in the uptake of a wide variety of metals (e.g. $\mathrm{Zn}, \mathrm{Ni}, \mathrm{As}, \mathrm{Cu}, \mathrm{Co}, \mathrm{Pb}$ ) and radioactive elements ( $\mathrm{Ra}, \mathrm{Pu}$ ) was demonstrated (Herczeg et al., 1988; Müller et al., 2002; O'Reilly and Hochella, 2003; Tebo et al., 2004; Hochella et al., 2005; Manceau et al., 2005; Powell et al., 2006). Currently, the role of Mn oxides, relative to Fe oxides for controlling $U$ mobility remains unclear. For instance, Andersson et al. (1995) have related the significant removal of $U$ from the Baltic Sea water column to the large precipitation of some authigenic Mn oxyhydroxides. In contrast, the sequential leaching of 
oceanic Fe-Mn crusts or soils suggests that $U$ would be preferentially associated to Fe oxides rather than Mn oxides (Koschinsky and Hein, 2003; Aubert et al., 2004), but these results do not take into account the relative abundance of each oxide in the leached material (the total amount rather than the concentration of $U$ in $M n$-oxides relative to Fe-oxides is usually reported), hence the specific affinity of $U$ for each phase was not properly assessed. Without doubt, the geochemical conditions ( $\mathrm{pH}$, Eh, presence of organic matter and ionic strength), but also the nature of the Mn oxides must influence the extent of the potential interaction of $U$ with these phases. The generic name "Mn oxides" indeed regroups a large diversity of mineral structures (Giovanoli et al., 1970; Post, 1999). Among them, the birnessite-type group includes the "3D-ordered" and micrometric buserite and birnessite, as well as the randomly stacked and poorly crystalline vernadite and its synthetic analog $\delta-\mathrm{MnO}_{2}$ (Giovanoli et al., 1970). These birnessite-type layered structures are the most common Mn oxides in oceanic nodules and crusts (Crerar and Barnes, 1974; Burns and Burns, 1979), hemipelagic, lake and surface sediments (Tipping et al., 1984; Müller et al., 2002; Bodeï et al., 2007) or in soils (Dixon and Skinner, 1992; Post, 1999; Palumbo et al., 2001; Manceau et al., 2002b; Manceau et al., 2003; Isaure et al., 2005). These oxides are also present in the alteration products of nuclear waste glasses (Abrajano et al., 1990; Buck and Bates, 1999). More specifically, the hexagonal form of birnessite would most accurately represent the essential features of oxides found in acidic soils (Chukhrov et al., 1985; Friedl et al., 1997), as well as the biogenic Mn oxides produced by micro-organisms in soils and freshwater environments or in seawater (Bargar et al., 2000b; Villalobos et al., 2003; Jürgensen et al., 2004; Bargar et al., 2005; Villalobos et al., 2006; Bargar et al., 2009).

Webb et al. (2006) have proposed a first comprehensive model of $U$ adsorption onto biogenic Mn oxides, further recently completed by Wang et al. (2013) for inorganic Mn oxides. This latter study was however conducted onto poorly crystalline nano-size $\delta-\mathrm{MnO}_{2}$ particles. Some recent studies pointed out the influence of the particle size on metal adsorption due to the potential difference in nanoparticle surfaces structures relative to larger particles (Madden et al., 2006; Zeng et al., 2009). Moreover, the influence of 3D-order on the sorption capacity and on sorption sites remains unclear. This study hence presents the results of the experimental sorption of $\mathrm{U}^{\mathrm{VI}}$ onto large and 3D-ordered hexagonal birnessite particles for diluted conditions relevant to natural uncontaminated environments. A model of surface complexation was developed to describe and quantify the observed sorption of $\mathrm{U}^{\mathrm{VI}}$, coupled with in-situ spectroscopic investigation (EXAFS) in order to precisely define the crystallographic site(s) of sorbed $U^{\mathrm{VI}}$ on the birnessite surface.

\section{Materials and methods}

\subsection{Birnessite synthesis and characterization}

The crystalline structure of buserite and its conversion to birnessite was extensively studied (Manceau et al., 1992b; Drits et al., 1997; Manceau et al., 1997; Silvester et al., 1997; Lanson et al., 2000). These studies have established that Na-rich buserite (10 Å layer spacing) converts to a $7 \AA$ layer spacing hexagonal birnessite in acidic medium. This conversion results in the formation of vacant layer sites and to the loss of the exchangeable cations from the interlayer space (Fig. 1). The layer charge is thus compensated by interlayer protons and $\mathrm{Mn}^{3+}$ and $\mathrm{Mn}^{2+}$ cations (Drits et al., 1997; Silvester et al., 1997; Lanson et al., 2000; Lanson et al., 2002a)

Hexagonal birnessite (hereafter named H-birnessite) was synthesized by acidification of a triclinic Na-buserite $\left(\mathrm{Na}_{0.31} \mathrm{Mn}^{4+}{ }_{0.69} \mathrm{Mn}^{3+}{ }_{0.31}\right.$. $\mathrm{nH}_{2} \mathrm{O}$ (Silvester et al., 1997; Lanson et al., 2002a)) according to the protocol described by Giovanoli et al. (1970), and detailed in the electronic supplementary appendix S1.1. For the various experiments (surface charge, $\mathrm{U}^{\mathrm{VI}}$ sorption isotherms or EXAFS measurements)

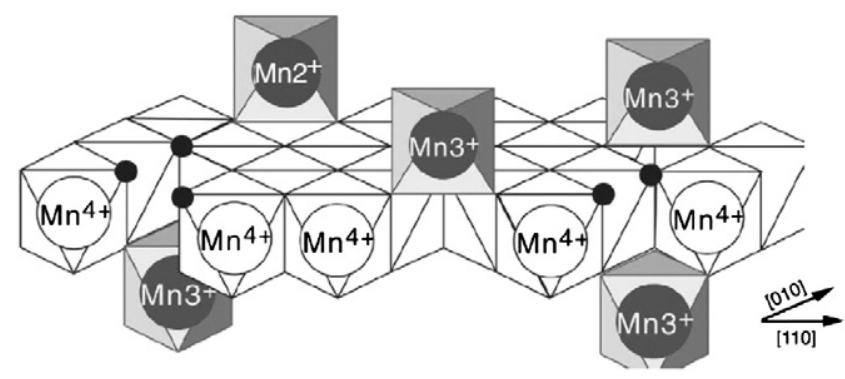

Fig. 1. Structure of hexagonal birnessite, showing the layer vacancies and the $\mathrm{Mn}^{\text {II, III }}$ octahedra located above and below these vacancies. From Lanson et al. (2000).

H-birnessite was prepared by equilibration to low $\mathrm{pH}$ of $\sim 1 \mathrm{~g}$ of Na-buserite which was suspended in $300 \mathrm{~mL} 0.1 \mathrm{M} \mathrm{NaClO}_{4}$ (or $\mathrm{NaNO}_{3}$ and $\mathrm{Na}_{2} \mathrm{CO}_{3}$ for some EXAFS samples, Table 1) and continuously maintained in inert $\mathrm{Ar}$ atmosphere. Perchlorate was used as the electrolyte anion to minimize metal-ligand complexation. The suspension was equilibrated within $24 \mathrm{~h}$ to $60 \mathrm{~h}$ to the target $\mathrm{pH}$ ranging from 3 to 6 (depending on the achieved experiments) by addition of $0.1 \mathrm{M} \mathrm{HCl}$ with an automatic titrator. Lanson et al. (2000) determined that the structural formula of the final product slightly varies with the activity of proton from $\mathrm{H}_{0.33}^{+} \mathrm{Mn}_{0.05}^{2+} \mathrm{Mn}_{0.111}^{3+}\left(\mathrm{Mn}_{0.722}^{4+} \mathrm{Mn}_{0.11}^{3+} \square_{0.167}\right) \mathrm{O}_{2}\left(\mathrm{H}_{2} \mathrm{O}\right)_{0.5}$ at pH 5 to $\mathrm{H}_{0.33}^{+} \mathrm{Mn}_{0.023}^{2+} \mathrm{Mn}_{0.143}^{3+}\left(\mathrm{Mn}_{0.722}^{4+} \mathrm{Mn}_{0.111}^{3+} \square_{0.167}\right) \mathrm{O}_{2}(\mathrm{OH})_{0.033}$ $\left(\mathrm{H}_{2} \mathrm{O}\right)_{0.467}$ at $\mathrm{pH} 3$.

Mineral identity and purity were controlled using X-ray powder diffraction (XRD) on randomly oriented powder which had been dried at $50{ }^{\circ} \mathrm{C}$ (Fig. S3 in the electronic supplementary appendix). The mineral was further characterized by a $\mathrm{N}_{2}$-BET specific surface area analysis and by Scanning Electron Microscopy (SEM), showing wellcrystallized particles with hexagonal platy morphology (Fig. S4 in the electronic supplementary appendix).

In order to accurately describe the sorption of $\mathrm{U}^{\mathrm{VI}}$ onto the $\mathrm{H}$-birnessite surface, a precise thermodynamical surface model of this mineral is needed. The surface charge of the $\mathrm{H}$-birnessite was therefore measured by potentiometric titration at $25{ }^{\circ} \mathrm{C}$ in $0.05 \mathrm{M} \mathrm{NaClO}_{4}$ background electrolyte (electronic supplementary appendix S1.2). Backtitration was performed in batch mode, allowing the analysis of the solids required for the calculation of the surface charge (Section 3.2). In addition, a fast and continuous back-titration of the same pH-3 suspension was also performed with a computer-controlled automatic Metrohm Dosimat 716. Following $\mathrm{NaOH}$ addition, the suspension EMF (ElectroMotive Force) was monitored with a Radiometer pH meter, once EMF drift was below $0.1 \mathrm{mV}$ per $60 \mathrm{~s}$ (Fig. S5 in the electronic supplementary appendix).

\subsection{Uranium adsorption}

$\mathrm{U}^{\mathrm{VI}}$ adsorption experiments onto H-birnessite were conducted in batches on suspensions previously equilibrated to the appropriate $\mathrm{pH}$ value $(3,4$ or 5$)$. Owing to the major change of the birnessite structure occurring near neutral $\mathrm{pH}$ (Silvester et al., 1997), $\mathrm{U}^{\mathrm{VI}}$ adsorption onto birnessite was not investigated above $\mathrm{pH} 6$. A detailed protocol, including the assessment of the lack of $\mathrm{U}^{\mathrm{VI}}$ sorption onto the vessels and filters, the lack of schoepite precipitation at higher $\mathrm{pH}$, and blank determination is provided in the electronic supplementary appendix S1.3. All the solutions were prepared from Milli-Q water boiled and bubbled with $\mathrm{Ar}$, and continuously maintained in inert $\mathrm{Ar}$ atmosphere in an airtight reactor (except for the experiment with $\mathrm{Na}_{2} \mathrm{CO}_{3}$ ). The initial concentrations of $\mathrm{U}^{\mathrm{VI}}$ ranged from $2.8 \times 10^{-7} \mathrm{M}$ to $4 \times 10^{-4} \mathrm{M}$. The solid-to-liquid (S/L) ratio in the suspensions was equal to $2.7 \mathrm{~g} / \mathrm{L}$. The equilibration time $(48 \mathrm{~h})$ was based on a series of preliminary kinetic experiments during which the solution composition was monitored over several days (Montes-Hernandez and Rihs, 2006). These experiments demonstrate that equilibrium of $U^{\mathrm{VI}}$ adsorption was achieved within 48 hours, 
Table 1

Experimental conditions of EXAFS-samples.

\begin{tabular}{|c|c|c|c|c|c|c|c|}
\hline & $\mathrm{pH}$ & Background & {$[\mathrm{U}]_{\text {initial }}(\mu \mathrm{mol} / \mathrm{L})$} & {$[\mathrm{U}]_{\text {sorbed }}(\mu \mathrm{mol} / \mathrm{g})$} & $\mathrm{U} / \mathrm{Mn}_{\text {solid }}(\mathrm{mol} / \mathrm{mol})$ & S.I. schoepite & \\
\hline Bi1 & 4 & $0.1 \mathrm{M} \mathrm{NaClO}_{4}$ & 10 & 1.1 & $1.0 \times 10^{-4}$ & -2.94 & U added before equilibration \\
\hline $\mathrm{Bi} 2$ & 4 & $0.1 \mathrm{M} \mathrm{NaClO}_{4}$ & 11 & 0.8 & $7.5 \times 10^{-5}$ & -2.95 & \\
\hline $\mathrm{Bi} 3$ & 4 & $0.1 \mathrm{M} \mathrm{NaNO}_{3}$ & 9 & 0.7 & $6.6 \times 10^{-5}$ & -3.06 & \\
\hline Bi4 & 4 & $0.1 \mathrm{M} \mathrm{NaClO}_{4}$ & 33 & 4.7 & $4.4 \times 10^{-4}$ & -2.43 & \\
\hline $\mathrm{Bi} 5$ & 5 & $0.1 \mathrm{M} \mathrm{NaClO}_{4}$ & 9 & 3 & $2.8 \times 10^{-4}$ & -1.62 & \\
\hline $\mathrm{Bi} 6$ & 6 & $0.1 \mathrm{M} \mathrm{NaClO}_{4}$ & 12 & 4.4 & $4.1 \times 10^{-4}$ & -0.54 & \\
\hline $\mathrm{Bi} 7$ & 6 & $0.1 \mathrm{M} \mathrm{Na}_{2} \mathrm{CO}_{3}$ & 10 & 3.7 & $3.5 \times 10^{-4}$ & -3.26 & \\
\hline $\mathrm{Bi} 8$ & 6 & $0.1 \mathrm{M} \mathrm{NaNO}_{3}$ & 13 & 5.1 & $4.8 \times 10^{-4}$ & -0.50 & \\
\hline
\end{tabular}

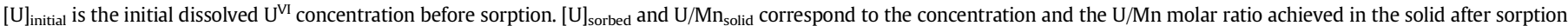

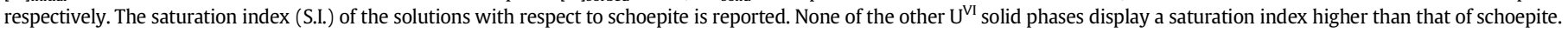

consistent with the previously reported adsorption of $U$ on iron oxides (Waite et al., 1994; Bargar et al., 2000a) or on $\delta-\mathrm{MnO}_{2}$ (Wang et al., 2013). It should however be noted that this time could correspond to the required time of birnessite re-equilibration after the slight disequilibrium initiated by addition of the $\mathrm{U}$ stock solution followed by $\mathrm{pH}$ adjustment rather than to kinetically-controlled sorption of $\mathrm{U}^{\mathrm{VI}}$.

The effect of the $\mathrm{S} / \mathrm{L}$ ratio on the $\mathrm{U}^{\mathrm{VI}}$ sorption was investigated during an additional set of experiments performed at $\mathrm{pH} 3$ for three initial $\mathrm{U}^{\mathrm{VI}}$ concentrations $\left(7 \times 10^{-7} \mathrm{M}, 2.3 \times 10^{-6} \mathrm{M}\right.$ and $\left.3.8 \times 10^{-6} \mathrm{M}\right)$. Varied amounts of solution were added to $100 \mathrm{mg}$ aliquots of hexagonal birnessite to reach S/L ratios ranging from 0.27 to $4.5 \mathrm{~g} / \mathrm{L}$. The sorption experiments with $\mathrm{U}^{\mathrm{VI}}$ were further conducted as described in the electronic supplementary appendix S1.3.

\subsection{Chemical analyses}

Analyses of $U$ concentrations were carried out by ICP-MS (Fisons VG-Plasma Quad ICP-MS). Certified Accu-Trace ${ }^{\mathrm{TM}}$ standard solutions were used as external standard. $\mathrm{Mn}, \mathrm{Na}$ and $\mathrm{K}$ concentrations were measured by atomic absorption spectrophotometry (AAS-Hitachi). The concentration of $\mathrm{Cl}$ was measured by ion chromatography (Dionex ICS-2000). The overall analytical reproducibility was $5 \%$ or better.

\subsection{Powder EXAFS spectroscopy}

\subsubsection{Sample preparation for EXAFS spectroscopy}

Eight samples of $\mathrm{U}^{\mathrm{VI}}$ sorbed onto birnessite were prepared for EXAFS spectroscopy, following the same procedure as for the U sorption study (Section 2.2) except for one sample (Bi1) for which $\mathrm{U}^{\mathrm{VI}}$ was added to the Na-buserite suspension before the equilibration to $\mathrm{pH} 4$ leading to the transformation of Na-buserite to H-birnessite. The experimental conditions for each sample are reported in Table 1. Moderate dissolved $\mathrm{U}^{\mathrm{VI}}$ concentrations $\left(10^{-5} \mathrm{M}\right.$ to $3.3 \times 10^{-5} \mathrm{M}$ ) were used in order to achieve $\mathrm{U} / \mathrm{Mn}$ molar ratios ranging from $6.6 \times 10^{-5}$ to $4.8 \times 10^{-4}$ in the solid that would allow to be detected at the ESRF ROBL beamline, while still being as close as possible to the natural Mn oxide concentration range. The equilibrium $\mathrm{pH}$ during $\mathrm{U}^{\mathrm{VI}}$ sorption was either 4,5 or 6 . Various background electrolytes $\left(0.1 \mathrm{M} \mathrm{NaClO}_{4}, \mathrm{NaNO}_{3}\right.$ or $\left.\mathrm{Na}_{2} \mathrm{CO}_{3}\right)$ were used to investigate the potential effect of the uranyl-anion complexation on the $\mathrm{U}^{\mathrm{VI}}$ sorption. After phases separation (by centrifugation), the powders were freeze-dried before they were pressed to pellets for powder EXAFS measurements.

\subsubsection{Data acquisition and reduction}

EXAFS measurements were performed on the BM20 ROBL beamline at ESRF (Grenoble, France), using a $\mathrm{Si}(111)$ double-crystal monochromator (Reich et al., 2000). Uranium $\mathrm{L}_{\mathrm{III}}$-edge X-ray absorption spectra were recorded at room temperature in fluorescence-yield detection mode using a multi-element Ge solid-state detector. For the preparation of the samples ultra-pure reagents were used in order to avoid an interfering fluorescence signal of the $\mathrm{Sr} \mathrm{K} \alpha$ line at $14.2 \mathrm{keV}$. A vanadium metal foil was used to attenuate the $\mathrm{Mn} \mathrm{K} \alpha$ fluorescence from the substrate. Owing to the low U/Mn ratios in the samples (Table 1), five to fifteen EXAFS scans were collected from each sample and averaged to improve the signal-to-noise ratio.

XAFS data reduction was made using the Athena software (Ravel and Newville, 2005). The analysis of the EXAFS data was carried out with the FEFFIT code (Newville et al., 1995), using phase and backscattering amplitude functions generated with the FEFF 8.1 code (Ankudinov and Rehr, 2000) from crystal structure data of andersonite where $\mathrm{Na}$ atoms were replaced by Mn atoms (Coda et al., 1981). Fits of the Fourier transform (FT) $k^{3}$-weighted EXAFS data to the EXAFS equation were performed in R-space between 0.6 and $4.0 \AA$. The $k$ range used was 3.7-14.6 $\AA^{-1}$. The amplitude reduction factor $\left(S_{0}^{2}\right)$ was held constant to 1 for all fits. The shift in the threshold energy $\left(E_{0}\right)$ was allowed in varying as a global parameter for all atoms. In all fits, the coordination number of the uranyl axial oxygen atoms $\left(\mathrm{O}_{\mathrm{ax}}\right)$ was held constant at two. The multiple scattering paths of the axial oxygens were included in the curve fit by constraining its effective path-length and its DebyeWaller factor to twice the values of the corresponding $\mathrm{U}-\mathrm{O}_{\mathrm{ax}}$ single scattering path (Hudson et al., 1996). In order to reduce the correlations between parameters (in particular $\mathrm{N}$ and $\sigma^{2}$ ), we have fixed the DebyeWaller factor of the Mn shell at a typical value $\left(0.005 \AA^{2}\right)$ (e.g.: Wang et al., 2013).

\section{Results}

\subsection{Mineral characterization}

The Mn content measured in the synthesized H-birnessite allows calculating a molar weight of $94.3 \mathrm{~g} / \mathrm{mol}$, in close agreement with the theoretical value of $96.2 \mathrm{~g} / \mathrm{mol}$ calculated from the H-birnessite formula (Lanson et al., 2000). Assuming that both sides of the basal surface of the unit cell are available for sorption, a theoretical specific surface area equal to $900 \mathrm{~m}^{2} / \mathrm{g}$ can be inferred from this molar weight and the unit cell parameters of H-birnessite refined by Lanson et al. (2000) (a $=4.94 \AA, \mathrm{b}=2.852 \AA$ ). This value significantly exceeds the measured $\mathrm{N}_{2}$-BET specific surface area $\left(\mathrm{S}_{\text {spec }}\right)$ of $14 \mathrm{~m}^{2} / \mathrm{g}$, but this latter method is known to underestimate the complete surface area of materials featuring outer as well as inner surfaces such as phyllo-silicates (e.g.: Metz et al., 2005) The SEM picture (Fig. S4) allows a rough geometrical estimate of the external surface of the H-birnessite particles. The mean $2 \times 2 \times 0.1 \mu \mathrm{m}$ observed particle-size would correspond to an external surface area of about $7 \mathrm{~m}^{2} / \mathrm{g}$ (assuming a $2.9 \mathrm{~g} / \mathrm{cm}^{3}$ density), close to the $\mathrm{N}_{2}$-BET surface measured for this sample, hence hinting that this latter value represents the mere external surface of the crystals. In the following sections, the theoretical basal value of $900 \mathrm{~m}^{2} / \mathrm{g}$ will be used as total surface area and the measured N2-BET surface will be used as external surface area to further model $\mathrm{H}$-birnessite surface complexation. The calculation of the theoretical edge surface in a $2 \times 2 \times 0.1 \mu \mathrm{m}$ particle demonstrates that this latter represents less than $0.1 \%$ of the basal surface. This surface was therefore neglected in the total surface area value. 


\subsection{Titration and surface charge model of H-birnessite}

Chemical analyses of each H-birnessite sample from the batch experiments reveal that these powders contain a significant and variable amount of $\mathrm{Na}$ and $\mathrm{K}$. Indeed, our experimental protocol to equilibrate birnessite to low $\mathrm{pH}$ implies that some $\mathrm{Na}$ ions were released into the solution from the Na-buserite and then re-adsorbed during the back titration experiments. Moreover, the specific sorption onto birnessite of $\mathrm{K}$ ions that were released into the solution from the $\mathrm{pH}$ electrode was accounted for. As demonstrated by Balistrieri and Murray (1982) for $\delta-\mathrm{MnO}_{2}$ in high ionic strength solution $\left(>10^{-2} \mathrm{M}\right)$, these cations would significantly participate to the net surface charge of the mineral, and must then be taken into account to accurately quantify the proton/ hydroxide surface site reactions. Accordingly, the net surface charge was calculated from the chemical analyses of the batch titration (described in the electronic supplementary appendix S2.1) and is shown in Fig. 2a. This curve is characterized by a constant, close to zero, surface charge between $\mathrm{pH} 2.9$ and $\mathrm{pH} 6$, reflecting the effect of the sorbed cations. The net surface charge starts to drop only above $\mathrm{pH}$ 6. This calculated charge is low when compared to the highly negative surface charge densities of birnessite or $\delta-\mathrm{MnO}_{2}$ published previously (reviewed in Peacock and Sherman (2007), Tonkin et al. (2004)). However, in all these studies the calculation of the surface charge was either based on the proton consumption during titration only, or did not involve Mn re-adsorption. Hence the difference probably arises from the
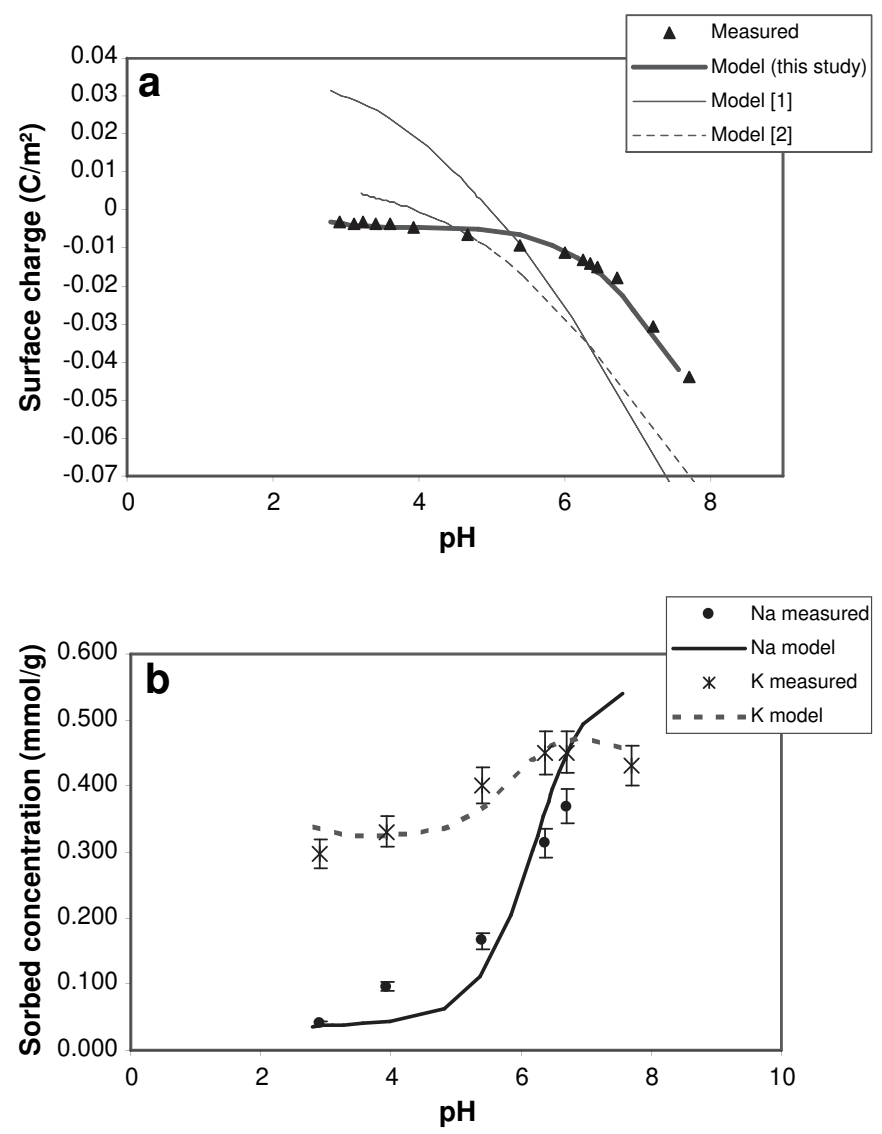

Fig. 2. Evolution of the net surface charge (a) and Na and K contents (b) of hexagonal birnessite with $\mathrm{pH}$. This charge was calculated according to Eq. S1 in the electronic supplementary appendix S2.1, including the contribution from $\mathrm{Na}$, $\mathrm{K}$ and $\mathrm{Mn}$ sorbed cations. Model [1] and Model [2] stand for a surface charge calculated with the complexation constants from Appelo and Postma (1999) and Tonkin et al. (2004) respectively. The optimization of surface complexation constants allows proposing a comprehensive model able to describe the particular flat shape of the net surface charge between $\mathrm{pH} 3$ and $\mathrm{pH} 6$, as well as the $\mathrm{Na}$ and $\mathrm{K}$ content evolution. contribution of the cations to the surface charge which is included in our surface charge determination (net total surface charge versus proton charge).

\section{3. $U^{V I}$ adsorption experiments}

The aqueous speciation of $\mathrm{U}^{\mathrm{VI}}$ in our experimental solutions was calculated using PHREEQC 2.18.3 (Parkhurst and Appelo, 1999). The wateq4f database was implemented with the $\mathrm{UO}_{2}(\mathrm{OH})_{2}$ species and the NEA-TBD recommended $\mathrm{U}^{\mathrm{VI}}$ aqueous equilibrium constants (Guillaumont et al., 2003). The solubility constants for schoepite and $\beta-\mathrm{UO}_{2}(\mathrm{OH})_{2}$ were taken equal to 5.39 (Critical Stability Constants of Metal Complexes Database, NIST Standard Reference Database 46 version 7) and 5.61 (Chemical Thermodynamics Database, NIST Standard Reference Database 2, version 1.1) respectively. These calculations demonstrate that uranyl-hydroxy species were predominant for the experiments at $\mathrm{pH} 5$ and the highest $\mathrm{U}^{\mathrm{VI}}$ concentration only, whereas at pH 3 and 4 the predominant dissolved species were uranyl ions. All the solutions (for the isotherm experiments as well as for EXAFS measurements) remain significantly under-saturated with respect to schoepite and other $\mathrm{U}^{\mathrm{VI}}$ solid phases (Table 1 and Fig. S6 in the electronic supplementary appendix), except for the highest $\mathrm{U}^{\mathrm{VI}}$ concentration in the $\mathrm{pH} 5$ isotherm, in which schoepite saturation index comes near to equilibrium ( $\mathrm{SI}=-0.02$ ). Nevertheless, our experiment of aging this latter solution (electronic supplementary appendix S1.3) demonstrates that no removal of $\mathrm{U}^{\mathrm{VI}}$ from the solution occurs without the addition of birnessite, confirming the absence of schoepite precipitation in these experiments.

Results from the isotherm adsorption experiments at $\mathrm{pH} 3,4$ and 5 are shown in Fig. 3. The concentration of sorbed $U^{\mathrm{VI}}$ ranges from $2.7 \times 10^{-8}$ to $3.4 \times 10^{-5} \mathrm{~mol} / \mathrm{g}$ for initial dissolved $\mathrm{U}^{\mathrm{VI}}$ concentration ranging from $2.8 \times 10^{-7}$ to $4.6 \times 10^{-4} \mathrm{M}$. Each isotherm is successfully described by a Langmuir adsorption equation:

$\mathrm{U}_{\mathrm{S}}=\frac{\mathrm{S}_{\mathrm{max}} \cdot \mathrm{K}_{\mathrm{L}} \cdot \mathrm{U}_{\mathrm{eq}}}{1+\mathrm{K}_{\mathrm{L}} \cdot \mathrm{U}_{\mathrm{eq}}}$

with $U_{\mathrm{S}}$ and $\mathrm{U}_{\mathrm{eq}}$ the $\mathrm{U}^{\mathrm{VI}}$ concentration in the solid ( $\mathrm{mol} / \mathrm{g}$ ) and in the final equilibrium solution $(\mathrm{M})$ respectively; $\mathrm{S}_{\max }$ the maximum sorption site density and $\mathrm{K}_{\mathrm{L}}$ the Langmuir constant. For $\mathrm{pH} 5$, the best fit of the data yields values of $\mathrm{S}_{\max }=36.6 \times 10^{-6} \mathrm{~mol} / \mathrm{g}$ and $\mathrm{K}_{\mathrm{L}}=4.58 \times$ $10^{4} \mathrm{~L} / \mathrm{mol}\left(\mathrm{R}^{2}=0.97\right)$. Using the measured BET external surface area $\left(14 \mathrm{~m}^{2} / \mathrm{g}\right)$, this $S_{\max }$ value would correspond to a site density of 1.57 sites $/ \mathrm{nm}^{2}$. Hence we tried to fit the $\mathrm{U}^{\mathrm{VI}}$ isotherms at $\mathrm{pH} 3$ and 4 with the same $S_{\max }$ value, adjusting the Langmuir constant $\mathrm{K}_{\mathrm{L}}$ only. This approach leads to poor fits, with a systematic lack of sorbed $U^{\mathrm{VI}}$ at low dissolved $\mathrm{U}^{\mathrm{VI}}$ concentrations. Both $\mathrm{S}_{\max }$ and $\mathrm{K}_{\mathrm{L}}$ should be adjusted to satisfactorily fit the isotherms at $\mathrm{pH} 3$ and 4 , suggesting the occurrence of, at least, two sites with different affinity and density during the $\mathrm{U}^{\mathrm{VI}}$ sorption process.

The effect of the $\mathrm{S} / \mathrm{L}$ ratio on the $\mathrm{U}^{\mathrm{VI}}$ sorption is reported in Fig. 4. For the three different $\mathrm{U}^{\mathrm{VI}}$ dissolved concentrations, the sorbed $\mathrm{U}^{\mathrm{VI}}$ concentrations display an unexpected $U$-shape behavior, decreasing when the $\mathrm{S} / \mathrm{L}$ ratio increases from $0.27 \mathrm{~g} / \mathrm{L}$ to $2.7 \mathrm{~g} / \mathrm{L}$, and then increasing for higher $\mathrm{S} / \mathrm{L}$ ratios.

\subsection{EXAFS results}

The $k^{3}$-weighted $\mathrm{U}_{\mathrm{III}}$-edge EXAFS data and the corresponding Fourier transform magnitudes (FTs) of all the samples are shown in Fig. 5. The distances $\mathrm{R}+\Delta \mathrm{R}$ in the FTs are reported in $\AA$ and are uncorrected for phase shifts. Comparison with previous studies demonstrates the similitude of global pattern of these spectra with the EXAFS spectra of $\mathrm{U}^{\mathrm{VI}}$ sorbed (at low coverage) onto Fe oxides (Waite et al., 1994; Reich et al., 1998; Bargar et al., 2000a; Rossberg et al., 2009), or onto Mn oxides 

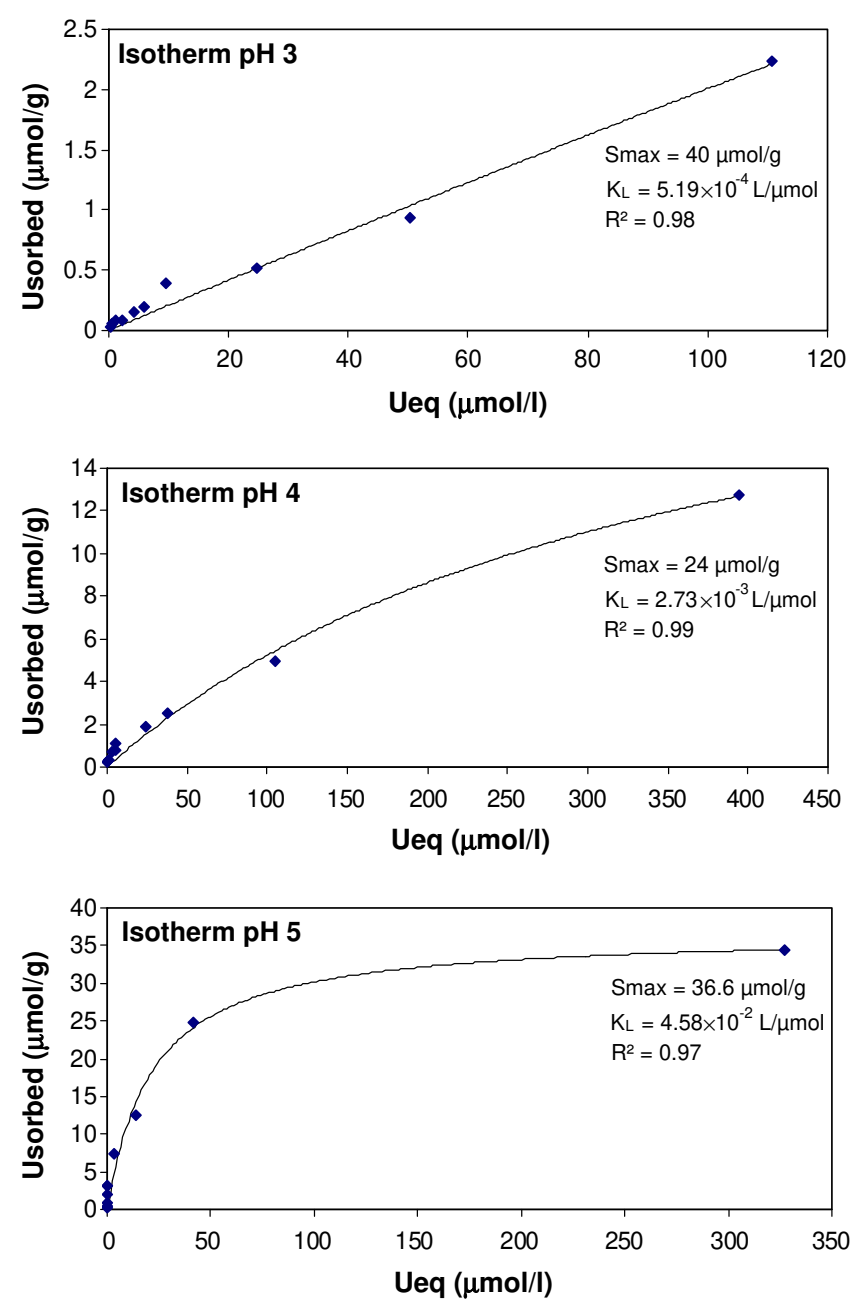

Fig. 3. Langmuir isotherms of $\mathrm{U}^{\mathrm{VI}}$ sorption onto hexagonal birnessite ( $\mathrm{pH} 3,4$ and 5). These isotherms demonstrate the $\mathrm{pH}$ dependence of the sorption constants.

(Webb et al., 2006; Wang et al., 2013), whereas $\mathrm{U}^{\mathrm{VI}}$ sorption at highcoverage and/or high $\mathrm{P}_{\mathrm{CO} 2}$ onto Fe oxides generate notably different EXAFS patterns (Bargar et al., 2000a; Sherman et al., 2008; Rossberg et al., 2009). Nevertheless, few differences arise in these spectra as

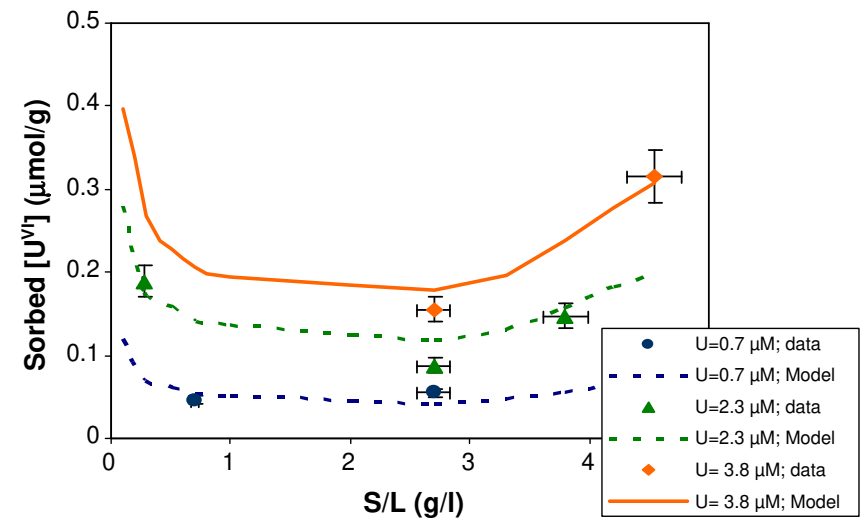

Fig. 4. Influence of the solid-to-liquid $(\mathrm{S} / \mathrm{L})$ ratio on the $\mathrm{U}^{\mathrm{VI}}$ sorption on $\mathrm{H}$-birnessite for three concentrations of dissolved $\mathrm{U}^{\mathrm{VI}}(0.7 \mu \mathrm{M}, 2.3 \mu \mathrm{M}$ and $3.8 \mu \mathrm{M}, \mathrm{pH}=3)$. The unexpected increase of $\mathrm{U}^{\mathrm{VI}}$ sorption at high $\mathrm{S} / \mathrm{L}$ ratios was successfully described by the proposed model. a function of $\mathrm{pH}$, such as a peak shoulder in the 7-8 $\AA^{-1}$ region for the $\mathrm{pH}-4$ samples that disappears in higher-pH samples (5 and 6), and a slight shift of the phase in the higher $k$ region for $\mathrm{pH}-6$ samples (Fig. 5c).

The FTs of the EXAFS spectra show, beyond the peak at $~ 1.4$ Å due to the two axial $O$ atoms of the uranyl moiety, two separate peaks at ca 1.8 and $2.2 \AA$, which are consistent with the backscattering from oxygen atoms lying in the equatorial plane of the uranyl moiety. A small feature at $3.0 \AA$ is visible for the $\mathrm{pH}-4$ and $\mathrm{pH}-5$ samples, but disappears for the samples at pH 6. In the lower-pH samples, this peak was found at the same radial distance, irrespective of the $\mathrm{U}^{\mathrm{VI}}$ loading. Both multiple scattering in the axial $\mathrm{O}=\mathrm{U}=\mathrm{O}$ unit or $\mathrm{Mn}$ second shell could give rise to FT features at about 2.9-3 $\AA$ (Hudson et al., 1996; Webb et al., 2006; Sherman et al., 2008). None of the spectra FTs shows significant intensity above $3 \AA$, precluding any backscattering from U neighbors, even at the highest $U$ loading.

These interpretations were corroborated by non-linear least squares curve fitting (Table 2). All samples show a split in the 0 equatorial shell, with backscatter distances of 2.29-2.32 Å and 2.45-2.46 A. Such a split suggests that one group of $O$ atoms forms bonds with the mineral surface and another group is coordinated by free hydroxo-groups, and is therefore attributed to the formation of inner-sphere complex with the mineral surface (Waite et al., 1994; Reich et al., 1998; Hudson et al., 1999). The FT feature at $3 \AA$ in the low-pH samples was successfully modeled by one U-Mn shell at 3.36-3.40 $\AA$, fully consistent with the U-Mn distance range (3.21-3.41 $\AA$ ) reported by Wang et al. (2013), Brennecka et al. (2011) and Webb et al. (2006) for uranyl complexes coordinated to $\delta-\mathrm{MnO}_{2}$ or biogenic birnessite-like Mn oxide surface in a bidentate edge-sharing fashion. In contrast, bidentate corner-sharing or monodentate binding to the mineral surface would produce a significantly larger U-Mn distance ( $\geq 3.8 \AA$ ).

No U-Mn shell was detected in the pH-6 samples. The disappearance of a Mn neighbor contribution in higher-pH samples implies that the surface species change in these samples. This change cannot be linked to the $\mathrm{U}^{\mathrm{VI}}$ surface coverage since a Mn neighbor contribution is detected in $\mathrm{Bi} 4(\mathrm{pH} 4)$ in which the $\mathrm{U} / \mathrm{Mn}$ ratio (Table 1 ) is higher than in Bi6-7 samples ( $\mathrm{pH}$ 6). The split of O equatorial shell in pH-6 samples rules out the presence of outer-sphere complexes. The absence of Mn neighbor at 3.4 Å in these samples seems more likely due to a coordination inducing larger U-Mn distance such as bidentate cornersharing or/and monodentate coordination, consistent with the results reported by Wang et al (2013) onto $\delta-\mathrm{MnO}_{2}$. In the present study, the U-Mn distance involved in such coordinations $(\sim 4.2 \AA)$ was beyond the resolution of the recorded spectra, owing the very low signal to noise ratio due to the low $\mathrm{U}^{\mathrm{VI}}$ concentration in the samples and the light mass of $\mathrm{Mn}$ atoms. It should be noted that the U/Mn molar ratios in our samples were about 2 orders of magnitude lower than the $\mathrm{U} / \mathrm{Mn}$ molar ratios in samples analyzed by Wang et al. (2013) $\left(\sim 4.5 \times 10^{-4}\right.$ vs. $\left.4.7 \times 10^{-2}\right)$. The study of Takahashi et al. (2007) clearly illustrates the decrease of FT peaks with $\mathrm{Pb}$ coverage on birnessite surface for a Pb-shell at $3.76 \AA$ A. This also suggests that a minor contribution of bidentate edge-sharing complexes could be insensible in our $\mathrm{pH}$ 6 samples.

No improvement in the fits of Bi7 was achieved by adding a $C$ shell from a carbonate group. No difference neither arises (EXAFS results, amount of sorbed $\mathrm{U}^{\mathrm{VI}}$ ) between the three samples (Bi6-8) prepared in different background solutions $\left(\mathrm{NaClO}_{4}, \mathrm{NaNO}_{3}, \mathrm{Na}_{2} \mathrm{CO}_{3}\right)$ at $\mathrm{pH} 6$. These results suggest a lack of ternary uranyl-carbonato complexes formation at $\mathrm{pH} \leq 6$, consistent with the recent conclusions of Rossberg et al. (2009). For the fit of Bi8 sample, prepared in $\mathrm{NaNO}_{3}$ background solution, the addition of a U-N shell (from a nitrate group) is possible but it results in a very slight improvement of the data fit $\left(\mathrm{R}_{\mathrm{factor}}=\right.$ 0.014 vs. 0.016 ). Such a shell would imply the formation of some ternary uranyl-nitrate complexes at the mineral surface. Finally, the lack of any detectable $\mathrm{U}-\mathrm{U}$ scattering pair is consistent with the thermodynamic calculations of the saturation indices of schoepite (Table 1). Moreover, 

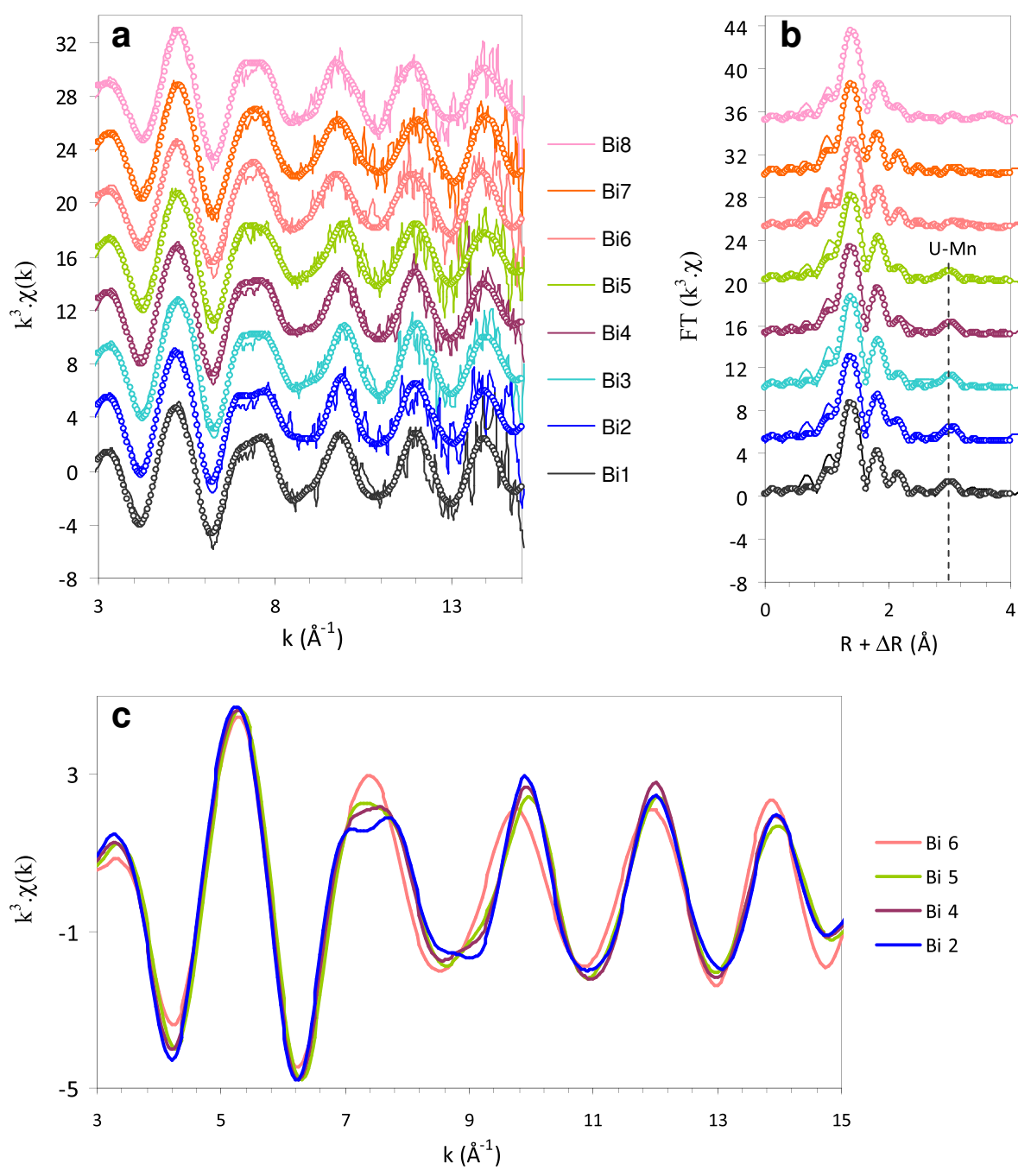

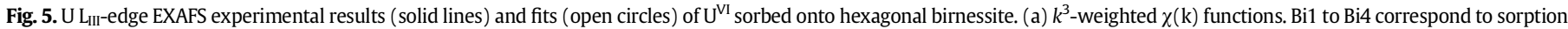

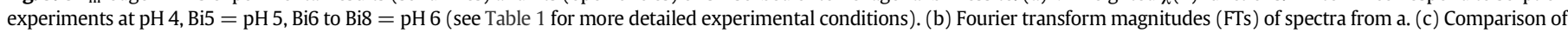

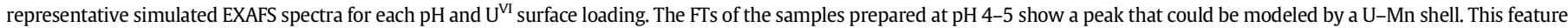
disappears in the samples at $\mathrm{pH}$, implying an evolution of $\mathrm{U}^{\mathrm{VI}}$ surface species with $\mathrm{pH}$.

it suggests that $\mathrm{U}^{\mathrm{VI}}$ does not form significant polynuclear $\mathrm{U}-\mathrm{U}$ species at the birnessite surface during sorption at $\mathrm{pH} \leq 6$.

Based on the split of the $\mathrm{O}$ equatorial shell, and the variable U-Mn contribution observed at different pHs, the EXAFS results support the conclusion that the sorption of the uranyl ions onto birnessite mostly occurs via an inner-sphere, mononuclear complexation mechanism, but several (at least two, maybe three) energetically different sites are involved in the sorption process. At low $\mathrm{pH}$ (4-5), a bidentate edgesharing coordination can be inferred, whereas bidentate cornersharing and/or monodentate complexation would most likely describe the EXAFS features of the samples at pH 6. Wang et al. (2013) proposed a similar coordination change with $\mathrm{pH}$, albeit this change was predicted to occur at a higher $\mathrm{pH}$ than what is observed in the present study ( $\sim \mathrm{pH} 7$ in the absence of dissolved carbonate ions).

\section{Discussion}

\subsection{Structural incorporation of $U^{V I}$}

Recent studies using spectroscopic techniques allow demonstrating that birnessite presents several types of sorption sites located in the interlayer, mostly depending on the structural form of birnessite, i.e.: monoclinic or hexagonal. While alkaline and alkaline-earth cations are located within the water sheet of monoclinic birnessite (Drits et al., 1997; Silvester et al., 1997; Axe et al., 2000; Lanson et al., 2002a) accounting for the reported cation-exchange capacity of this mineral (Post and Veblen, 1990; Post, 1999), hydrolysable cations such as Zn, $\mathrm{Pb}, \mathrm{Mn}, \mathrm{Ni}, \mathrm{Co}$ are mostly sorbed above and below the layer vacancies in hexagonal birnessite (Matocha et al., 2001; Lanson et al., 2002b; Manceau et al., 2002a; Li et al., 2004; Villalobos et al., 2005; Toner et al., 2006; Peacock and Sherman, 2007). In a few cases, incorporation of heavy metals into vacancies or substitution for Mn within the mineral lattice structure was reported (Manceau et al., 1997; Peacock and Sherman, 2007). In addition, external edge sites were explicitly recognized by spectroscopic techniques for As coordination to hexagonal birnessite (Tournassat et al., 2002) and for $\mathrm{Pb}$ and $\mathrm{U}$ sorption on biogenic birnessite-like Mn oxides (Villalobos et al., 2005; Webb et al., 2006), Fig. 6 illustrates the consequently possible $U^{\mathrm{VI}}$ sorption sites on hexagonal birnessite. In spite of the strong affinity of $U^{\mathrm{VI}}$ for interlayers of phyllosilicates such as smectites, vermiculites and biotites (Hudson et al., 1999; Chisholm-Brause et al., 2001; Catalano and Brown, 2005; Lee et al., 2009), several arguments suggest that $U^{\mathrm{VI}}$ does not enter into the interlayer of hexagonal birnessite in the present study, but instead sorbs on external sites only. Indeed, the interlayer space of hexagonal birnessite is significantly smaller than that of the phyllosilicates mentioned above, and the linear uranyl moiety presents much larger 
Table 2

EXAFS structural parameters for $\mathrm{U}^{\mathrm{VI}}$ sorbed onto birnessite. $\mathrm{R}_{\mathrm{factor}}$ gives the goodness of the fit. The errors on fitted parameters are: $N \pm 20 \%, R \pm 0.02 \AA, \sigma^{2} \pm 20 \%$.

\begin{tabular}{|c|c|c|c|c|c|c|}
\hline Sample & Shell & $\mathrm{N}$ & $\mathrm{R}(\AA)$ & $\sigma^{2}\left(\AA^{2}\right)$ & $\mathrm{E}_{0}(\mathrm{eV})$ & $\mathrm{R}_{\mathrm{factor}}$ \\
\hline Bi1 & $\mathrm{O}_{\mathrm{Ax}}$ & $2^{\mathrm{a}}$ & 1.79 & 0.002 & 8.3 & 0.02 \\
\hline $\mathrm{NaClO}_{4}$ & $\mathrm{O}_{\mathrm{eq} 1}$ & 2.2 & 2.30 & $0.003^{\mathrm{b}}$ & & \\
\hline $\mathrm{pH} 4$ & $\mathrm{O}_{\mathrm{eq} 2}$ & 2.2 & 2.45 & $0.003^{b}$ & & \\
\hline $10 \mu \mathrm{M}$ & $\mathrm{Mn}$ & 0.5 & 3.39 & $0.005^{\mathrm{a}}$ & & \\
\hline $\mathrm{Bi} 2$ & $\mathrm{O}_{\mathrm{Ax}}$ & $2^{\mathrm{a}}$ & 1.79 & 0.002 & 8.8 & 0.01 \\
\hline $\mathrm{NaClO}_{4}$ & $\mathrm{O}_{\mathrm{eq} 1}$ & 2.1 & 2.32 & $0.002^{\mathrm{b}}$ & & \\
\hline $\mathrm{pH} 4$ & $\mathrm{O}_{\mathrm{eq} 2}$ & 2.1 & 2.46 & $0.002^{\mathrm{b}}$ & & \\
\hline $11 \mu \mathrm{M}$ & $\mathrm{Mn}$ & 0.6 & 3.40 & $0.005^{\mathrm{a}}$ & & \\
\hline $\mathrm{Bi} 3$ & $\mathrm{O}_{\mathrm{Ax}}$ & $2^{\mathrm{a}}$ & 1.79 & 0.002 & 8.9 & 0.02 \\
\hline $\mathrm{NaNO}_{3}$ & $\mathrm{O}_{\text {eq1 }}$ & 2.2 & 2.32 & $0.003^{b}$ & & \\
\hline $\mathrm{pH} 4$ & $\mathrm{O}_{\mathrm{eq} 2}$ & 1.6 & 2.46 & $0.003^{\mathrm{b}}$ & & \\
\hline $9 \mu \mathrm{M}$ & $\mathrm{Mn}$ & 0.5 & 3.37 & $0.005^{\mathrm{a}}$ & & \\
\hline Bi4 & $\mathrm{O}_{\mathrm{Ax}}$ & $2^{\mathrm{a}}$ & 1.80 & 0.002 & 9.1 & 0.01 \\
\hline $\mathrm{NaClO}_{4}$ & $\mathrm{O}_{\mathrm{eq} 1}$ & 2.2 & 2.32 & $0.002^{\mathrm{b}}$ & & \\
\hline $\mathrm{pH} 4$ & $\mathrm{O}_{\text {eq2 }}$ & 1.7 & 2.46 & $0.002^{\mathrm{b}}$ & & \\
\hline $33 \mu \mathrm{M}$ & $\mathrm{Mn}$ & 0.5 & 3.39 & $0.005^{\mathrm{a}}$ & & \\
\hline $\mathrm{Bi} 5$ & $\mathrm{O}_{\mathrm{Ax}}$ & $2^{\mathrm{a}}$ & 1.80 & 0.002 & 9.3 & 0.02 \\
\hline $\mathrm{NaClO}_{4}$ & $\mathrm{O}_{\text {eq1 }}$ & 2.2 & 2.32 & $0.003^{b}$ & & \\
\hline pH 5 & $\mathrm{O}_{\text {eq2 }}$ & 1.7 & 2.46 & $0.003^{\mathrm{b}}$ & & \\
\hline $9 \mu \mathrm{M}$ & $\mathrm{Mn}$ & 0.3 & 3.36 & $0.005^{\mathrm{a}}$ & & \\
\hline $\mathrm{Bi} 6$ & $\mathrm{O}_{\mathrm{Ax}}$ & $2^{\mathrm{a}}$ & 1.81 & 0.002 & 10.0 & 0.01 \\
\hline $\begin{array}{l}\mathrm{NaClO}_{4} \\
\mathrm{pH} 6\end{array}$ & $\mathrm{O}_{\mathrm{eq} 1}$ & 1.8 & 2.30 & $0.002^{\mathrm{b}}$ & & \\
\hline $12 \mu \mathrm{M}$ & $\mathrm{O}_{\mathrm{eq} 2}$ & 1.6 & 2.46 & $0.002^{\mathrm{b}}$ & & \\
\hline $\mathrm{Bi} 7$ & $\mathrm{O}_{\mathrm{Ax}}$ & $2^{\mathrm{a}}$ & 1.80 & 0.002 & 8.3 & 0.01 \\
\hline $\begin{array}{l}\mathrm{NaCO}_{3} \\
\mathrm{pH} 6\end{array}$ & $\mathrm{O}_{\mathrm{eq} 1}$ & 2.2 & 2.29 & $0.003^{b}$ & & \\
\hline $10 \mu \mathrm{M}$ & $\mathrm{O}_{\mathrm{eq} 2}$ & 2.0 & 2.45 & $0.003^{\mathrm{b}}$ & & \\
\hline $\mathrm{Bi} 8$ & $\mathrm{O}_{\mathrm{Ax}}$ & $2^{\mathrm{a}}$ & 1.81 & 0.002 & 9.9 & 0.016 \\
\hline $\mathrm{NaNO}_{3}$ & $\mathrm{O}_{\mathrm{eq} 1}$ & 1.8 & 2.31 & $0.005^{\mathrm{b}}$ & & \\
\hline pH 6 & $\mathrm{O}_{\text {eq2 }}$ & 1.8 & 2.45 & $0.005^{\mathrm{b}}$ & & \\
\hline $13 \mu \mathrm{M}$ & $\mathrm{N}$ & 0.6 & 2.96 & $0.005^{\mathrm{a}}$ & & 0.014 \\
\hline
\end{tabular}

steric obstruction than $\mathrm{Zn}$, Pb, or Ni. Moreover, a significant uptake of $\mathrm{U}^{\mathrm{VI}}$ in ion-exchange sites is precluded here since: i) a high ionic strength is used for the sorption experiments ( $0.1 \mathrm{M} \mathrm{NaClO} 4)$, and ii) our EXAFS results suggest inner-sphere complex formation. Consistently, results from the Bi1 sample (Table 1) support this assumption. In this sample, the $\mathrm{U}^{\mathrm{VI}}$ was added to the birnessite suspension before its conversion to H-birnessite; i.e.: before the dehydration yielding to the collapse of the $10 \AA$ layer spacing to $7 \AA$, hence favoring the entry of $U^{\mathrm{VI}}$ into the interlayer space. However, no difference with the related sample Bi2 (addition of $\mathrm{U}^{\mathrm{VI}}$ after the achievement of $\mathrm{H}$-birnessite conversion) was observed, neither in $\mathrm{U}^{\mathrm{VI}}$ uptake (sorbed concentrations or EXAFS

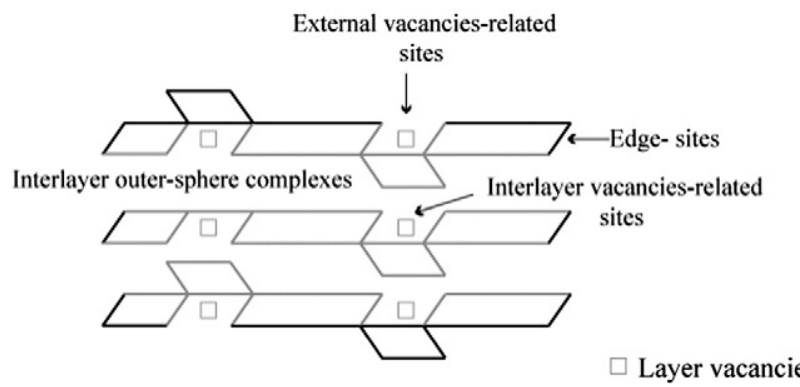

Fig. 6. Sketch of hypothetical $\mathrm{U}^{\mathrm{VI}}$ sorption sites on hexagonal birnessite. Inner-sphere complexation above layer vacancies represents preferential sorption sites for numerous hydrolysable cations (Matocha et al., 2001; Lanson et al., 2002b; Villalobos et al., 2005; Toner et al., 2006; Peacock and Sherman, 2007). By analogy with the previously reported $\mathrm{U}^{\mathrm{VI}}$ sorption schemes on various oxide surfaces (Waite et al., 1994; Rossberg et al., 2009), edge-sites can also be expected. Finally, owing to structural similarity between birnessite and clays (layered structure and permanent layer charge) and the affinity of $\mathrm{U}^{\mathrm{VI}}$ for interlayers of phyllosilicates (e.g. Chisholm-Brause et al., 2001; Catalano and Brown, 2005), $\mathrm{U}^{\mathrm{VI}}$ sorption as outer-sphere in the interlayer could tentatively be assumed under certain conditions. results) nor in XRD pattern of the final oxide (Fig S1b in electronic supplementary appendix).

A careful examination of the H-birnessite surface provides some constraint on the different sites put forward by EXAFS data. At low $\mathrm{pH}$, the EXAFS model implies a bidentate edge-sharing binding that rules out the positioning of $\mathrm{U}^{\mathrm{VI}}$ above the layer vacancies. Most likely, the Mn octahedra of the particle edges would provide adequate environment for such binding (strong-affinity site in Fig. 7). At least one of the unshared-edge length of Mn octahedra from the particle edge (2.76 A) (Manceau et al., 2002a) closely matches the O-O equatorial distance in uranyl moiety (2.73 Å for an equatorial fivefold coordination (Burns et al., 1997; Evans, 1963)). With a mean U-O $\mathrm{O}_{\mathrm{eq}}$ distance of 2.46 $\AA$ (from our EXAFS results), an edge length of $2.76 \AA$ would lead to a theoretical U-Mn distance of $3.35 \AA$, perfectly consistent with the measured value (3.36-3.40 $\AA$ ). Because the complexation of $\mathrm{U}^{\mathrm{VI}}$ to these sites is very strong, in spite of the inauspicious sorption conditions (low $\mathrm{pH}$, low dissolved $\mathrm{U}$ concentration), an energetically high affinity between $\mathrm{U}^{\mathrm{VI}}$ and these sites must be assumed. When the $\mathrm{pH}$ increases, EXAFS results evoke the emergence of at least one additional binding geometry, involving either bidentate corner-sharing or monodentate binding. The density of these latter must be large enough to account for the highest amount of sorbed $\mathrm{U}^{\mathrm{VI}}$, albeit with lower affinity than the bidentate edge-sharing sites. The positive comparison between the maximum site-density inferred from the pH-5 Langmuir isotherm (1.57 sites $/ \mathrm{nm}^{2}$ ) and the calculated theoretical density of uncapped vacancies $\left(1.53\right.$ sites $/ \mathrm{nm}^{2}$, see Section 4.2 and calculation details in the electronic supplementary appendix S2.2) suggests that the second type of sites involved in $\mathrm{U}^{\mathrm{VI}}$ sorption could be related to the $\mathrm{H}$-birnessite layer vacancies. Given the particular steric geometry of uranyl moiety, both bidentate corner-sharing and monodentate geometries above layer vacancies can be assumed, with an orientation of the uranyl axis parallel to the birnessite surface (Fig. 7). Such feature was previously observed in the vermiculite interlayer (Hudson et al., 1999). In the bidentate corner-sharing configuration (weak affinity site in Fig. 7), the distance between the $O$ atoms of vacant octahedra (2.85-3.02 A, Manceau et al., 2002a) is slightly larger than the O-O equatorial distance in uranyl moiety, which could explain the lower affinity of $\mathrm{U}^{\mathrm{VI}}$ for this site, relative to the bidentate edge-sharing site described above. This model will be used to describe the measured isotherm data in a surface complexation framework.

\subsection{Surface complexation model}

Modeling $\mathrm{U}^{\mathrm{VI}}$ sorption at various $\mathrm{pHs}$ was achieved using a diffuse double layer model of surface complexation. This was completed within two steps. The $\mathrm{H} / \mathrm{Na} / \mathrm{K} / \mathrm{Mn}$ surface site reactions accounting for the net surface charge of the mineral surface (without $\mathrm{U}^{\mathrm{VI}}$ ) were first assessed in order to reproduce the surface charge and the evolution of $\mathrm{Na}$ and $\mathrm{K}$ contents shown in Fig. 2. In a second step, the mere $\mathrm{U}^{\mathrm{VI}}$ complexation constants were optimized to fit the measured isotherms (Fig. 8). Several models were published to describe the surface charge of Mn oxides (reviewed in Tonkin et al. (2004), Peacock and Sherman (2007)). Unfortunately, most of them model the Mn-oxide proton surface charge only, which is inadequate to describe the net surface charge calculated in the present study (including $\mathrm{Na} / \mathrm{K} / \mathrm{Mn}$ participation). Among the most recent published models, only Tonkin et al. (2004) and Appelo and Postma (1999) proposed complexation constants for Mn ions, and merely this latter work includes $\mathrm{Na}$ and $\mathrm{K}$ complexation constants. Models and complexation constants from Tonkin et al. (2004) or Appelo and Postma (1999) were implemented in the program PHREEQC (Parkhurst and Appelo, 1999) in order to reproduce the net surface charge from our titration experiment conditions $(\mathrm{I}=0.05 \mathrm{M}$; $\mathrm{S} / \mathrm{L}$ ratio $=2.2 \mathrm{~g} / \mathrm{L}$ ), but none of the calculated surface charge accurately fits our data (Fig. 2a, models [1] and [2]). No improvement of the fit was achieved by adjusting the birnessite specific surface area or surface site density. Specifically, these models were unable to reproduce the 


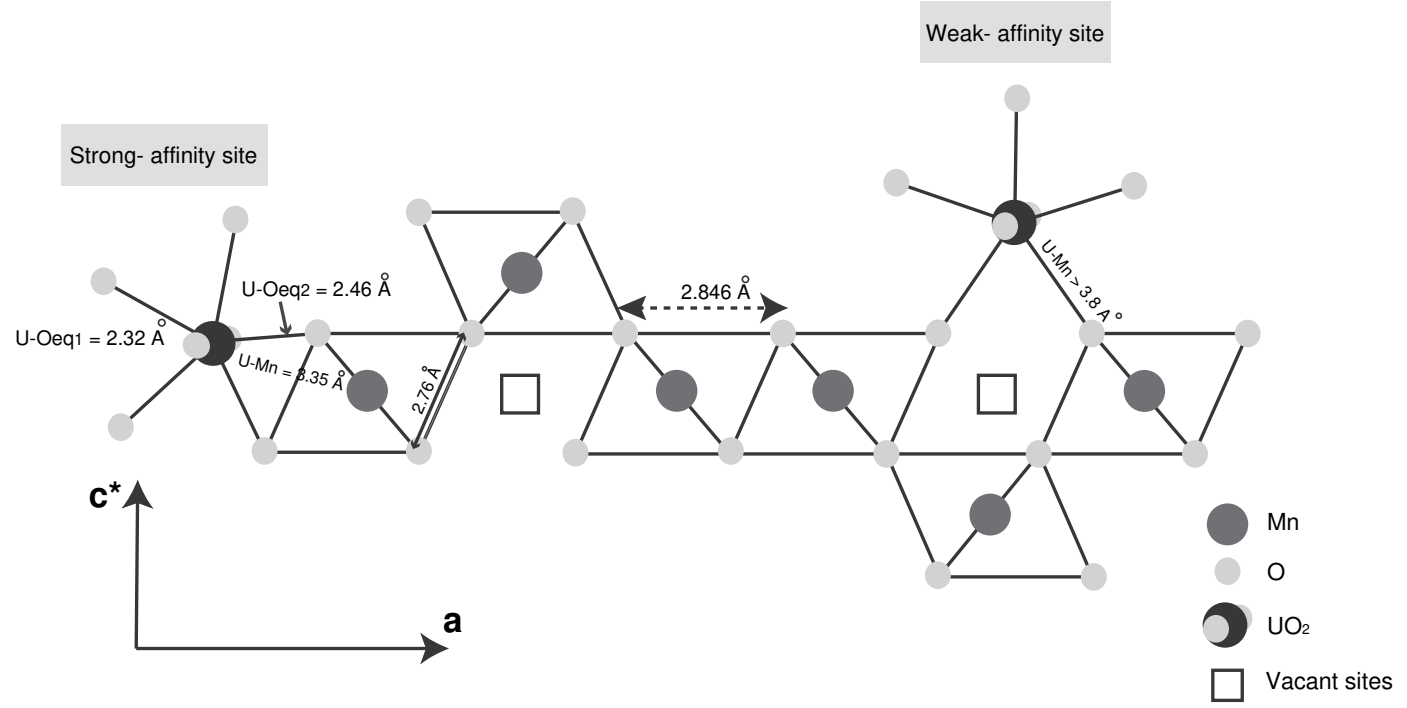

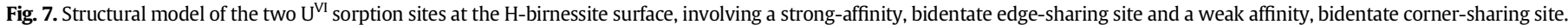
For clarity purposes, monodentate coordination for the weak affinity site was omitted. Structural parameters for H-birnessite from Lanson et al. (2000) and Manceau et al. (2002a).

particular flat shape of the net surface charge between $\mathrm{pH} 3$ and $\mathrm{pH} 6$. Determination of specific complexation constants was thus mandatory to accurately model our birnessite surface, and further $\mathrm{U}^{\mathrm{VI}}$ sorption. Because the diprotic model of Appelo and Postma (1999) is based on crystallographic data perfectly consistent with our synthetic birnessite, this model was considered to fit our data, but complexation constants and surface site densities were re-addressed. Detailed informations on this model and optimization are given in the electronic supplementary appendix S2.2. The theoretical basal site density was taken equal to the number of vacant sites which are not capped by interlayer Mn octahedra ("uncapped" sites) (Figs. 1 and 6), i.e.: 1.53 sites $/ \mathrm{nm}^{2}$ (see calculation in S2.2). Results from the optimization are reported in Table 3. Fig. 2 shows the modeled surface charge and sorbed Na and K amounts using these constants, along with experimental data.

These constants were further used for the optimization of the $\mathrm{U}^{\mathrm{VI}}$ complexation constants. Two distinct surfaces were hence included in the model: a total surface mostly representing internal basal surface $\left(900 \mathrm{~m}^{2} / \mathrm{g}\right.$ ) onto which only $\mathrm{H}, \mathrm{Mn}$, Na or $\mathrm{K}$ were assumed to sorb, and an external surface $\left(14 \mathrm{~m}^{2} / \mathrm{g}\right)$ onto which the sorption of the $\mathrm{U}^{\mathrm{VI}}$ ions was modeled. In a preliminary attempt, the fit of the measured $\mathrm{U}^{\mathrm{VI}}$ isotherms with only one type of sorption site onto birnessite surface failed, consistently to what was earlier found to be the case for $\mathrm{U}^{\mathrm{VI}}$ sorption onto Fe-oxides (Waite et al., 1994; Fox et al., 2006; Gustafsson et al., 2009; Zeng et al., 2009). No improvement was achieved when uranylhydroxy species were added to the model. This model was unable to

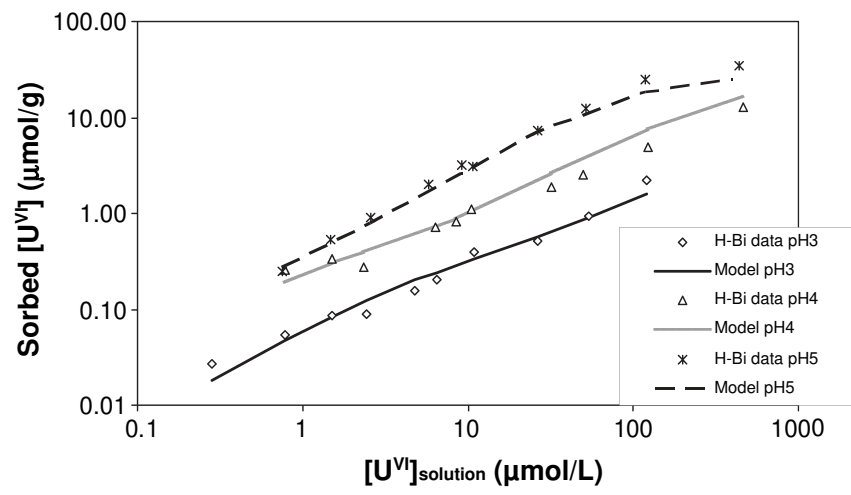

Fig. 8. Model of $\mathrm{U}^{\mathrm{VI}}$ sorption onto hexagonal birnessite ( $\mathrm{pH} 3,4$ and 5$)$. $\left[\mathrm{U}^{\mathrm{VI}}\right]_{\text {solution }}$ corresponds to initial concentration. adequately fit both the low- and high-U concentration parts of the isotherms at the same time.

We therefore developed a model deduced from EXAFS data, involving two types of binding sites located on the particle external surface. A strong-affinity, bidentate edge-sharing complexation was described, following:

$$
\equiv \mathrm{Mn}_{\mathrm{s}}(\mathrm{OH})_{2}+\mathrm{UO}_{2}{ }^{2+}=\equiv \mathrm{Mn}_{\mathrm{s}} \mathrm{O}_{2} \mathrm{UO}_{2}+2 \mathrm{H}^{+}
$$

where $\equiv \mathrm{Mn}_{\mathrm{s}}(\mathrm{OH})_{2}$ corresponds to a bidentate site and the subscript $\mathrm{s}$ stands for strong-binding site.

Following the same formalism as for the model Appelo and Postma (1999) used for surface charge description (electronic supplementary appendix S2.2), a weak-affinity complexation involving either bidentate corner-sharing or monodentate binding to layer vacancies was described, following:

$$
\left.\mid \begin{array}{l}
\equiv \mathrm{S}_{\mathrm{w}} \mathrm{O}_{3} \mathrm{H}_{2}+\mathrm{UO}_{2}^{2+}=\equiv \mathrm{S}_{\mathrm{w}} \mathrm{O}_{3} \mathrm{UO}_{2}+2 \mathrm{H}^{+} \\
\equiv \mathrm{S}_{\mathrm{w}} \mathrm{O}_{3} \mathrm{H}_{2}+\mathrm{UO}_{2}^{2+}=\equiv \mathrm{S}_{\mathrm{w}} \mathrm{O}_{3} \mathrm{HUO}_{2}^{+}+\mathrm{H}^{+}
\end{array}\right\}
$$

Table 3

Complexation constants optimized from our experimental data for surface charge model, using the diprotic model of Appelo and Postma (1999) and for $\mathrm{U}^{\mathrm{VI}}$ sorption onto birnessite surface.

\begin{tabular}{lcl}
\hline Reaction & Log K & Site density $\left(\right.$ sites $\left./ \mathrm{nm}^{2}\right)$ \\
\hline$\equiv \mathrm{SO}_{3} \mathrm{H}_{2}=\equiv \mathrm{SO}_{3} \mathrm{H}^{-}+\mathrm{H}^{+}$ & 0.6 & $1.53^{\mathrm{b}}$ \\
$\equiv \mathrm{SO}_{3} \mathrm{H}_{2}=\equiv \mathrm{SO}_{3}^{2-}+2 \mathrm{H}$ & -9 & $"$ \\
$\equiv \mathrm{SO}_{3} \mathrm{H}_{2}+\mathrm{H}^{+}=\equiv \mathrm{SO}_{3} \mathrm{H}_{3}^{+}$ & $1.84 \mathrm{a}$ & $"$ \\
$\equiv \mathrm{SO}_{3} \mathrm{H}_{2}+\mathrm{H}^{+}+\mathrm{Cl}^{-}=\equiv \mathrm{SO}_{3} \mathrm{H}_{3} \mathrm{Cl}$ & $3.28^{\mathrm{a}}$ & $"$ \\
$\equiv \mathrm{SO}_{3} \mathrm{H}_{2}+\mathrm{Mn}^{2+}=\equiv \mathrm{SO}_{3} \mathrm{HMn}^{+}+\mathrm{H}^{+}$ & 3.75 & $"$ \\
$\equiv \mathrm{SO}_{3} \mathrm{H}_{2}+\mathrm{Mn}^{2+}=\equiv \mathrm{SO}_{3} \mathrm{Mn}+2 \mathrm{H}^{+}$ & -2.7 & $"$ \\
$\equiv \mathrm{SO}_{3} \mathrm{H}_{2}+\mathrm{Na}^{+}=\equiv \mathrm{SO}_{3} \mathrm{HNa}+\mathrm{H}^{+}$ & 0.4 & $"$ \\
$\equiv \mathrm{SO}_{3} \mathrm{H}_{2}+\mathrm{Na}^{+}=\equiv \mathrm{SO}_{3} \mathrm{Na}^{-}+2 \mathrm{H}^{+}$ & -4.5 & $"$ \\
$\equiv \mathrm{SO}_{3} \mathrm{H}_{2}+\mathrm{K}^{+}=\equiv \mathrm{SO}_{3} \mathrm{HK}^{+} \mathrm{H}^{+}$ & 3 & $"$ \\
$\equiv \mathrm{SO}_{3} \mathrm{H}_{2}+\mathrm{K}^{+}=\equiv \mathrm{SO}_{3} \mathrm{~K}^{-}+2 \mathrm{H}^{+}$ & -2.7 & $"$ \\
$\equiv \mathrm{Mn}_{\mathrm{s}}(\mathrm{OH})_{2}+\mathrm{UO}_{2}^{2+}=\equiv \mathrm{Mn}_{\mathrm{s}} \mathrm{O}_{2} \mathrm{UO}_{2}+2 \mathrm{H}^{+}$ & 3.15 & 0.0134 \\
$\equiv \mathrm{S}_{\mathrm{w}} \mathrm{O}_{3} \mathrm{H}_{2}+\mathrm{UO}_{2}^{2+}=\equiv \mathrm{S}_{\mathrm{w}} \mathrm{O}_{3} \mathrm{UO}_{2}+2 \mathrm{H}^{+}$ & 0.12 & $1.57^{\mathrm{c}}$ \\
$\equiv \mathrm{S}_{\mathrm{w}} \mathrm{O}_{3} \mathrm{H}_{2}+\mathrm{UO}_{2}^{2+}=\equiv \mathrm{S}_{\mathrm{w}} \mathrm{O}_{3} \mathrm{HUO}_{2}^{+}+\mathrm{H}^{+}$ & 3.348 & $1.57^{\mathrm{c}}$ \\
\hline
\end{tabular}

$\mathrm{s}$ and $\mathrm{w}$ subscripts stand for strong and weal sites respectively

a From Appelo and Postma (1999).

b Theoretical "uncapped" vacant sites (detailed calculation in the electronic supplementary annex S2.2).

c Deduced from the maximum sorption density of $\mathrm{pH}-5$ isotherm. 
where $\equiv \mathrm{S}_{\mathrm{w}} \mathrm{O}_{3} \mathrm{H}_{2}$ is a doubly charged multi-oxygen site corresponding to the crystallographic lattice vacancies, and the subscript w stands for weak-binding sites.

The total external site density was taken equal to 1.57 sites $/ \mathrm{nm}^{2}$ (maximum site-density inferred from the Langmuir isotherm at $\mathrm{pH} 5$ ). The strong-affinity site density was optimized using the PEST program (Doherty, 2004), in addition to the three $\mathrm{U}^{\mathrm{VI}}$ surface complexation constants. The best fit is shown in Fig. 8, and the corresponding constants are reported in Table 3. Consistent to the lack of polynuclear sorbed species suggested by the EXAFS data, no improvement of the fit was achieved by adding the sorption of some uranyl-hydroxy species. Fig. 9 shows the evolution of the sorbed species with $\mathrm{pH}$ and initial dissolved $\mathrm{U}^{\mathrm{VI}}$ concentration as predicted by the model. These results suggest that at $\mathrm{pH} 4$, the strong-affinity $\equiv \mathrm{Mn}_{\mathrm{s}} \mathrm{O}_{2} \mathrm{UO}_{2}$ species is prevailing up to an initial $U^{\mathrm{VI}}$ concentration of about $0.8 \times 10^{-5} \mathrm{M}$, whereas a mixture of the three species dominates above this $\mathrm{U}^{\mathrm{VI}}$ concentration. For the samples Bi1 to Bi4 conditions, the predicted coexistence of edgesharing and corner-sharing sorbed species is consistent with the mere $0.5 \pm 0.1 \mathrm{Mn}$ neighbors per $\mathrm{U}$ atom at 3.39 Å detected by EXAFS. For
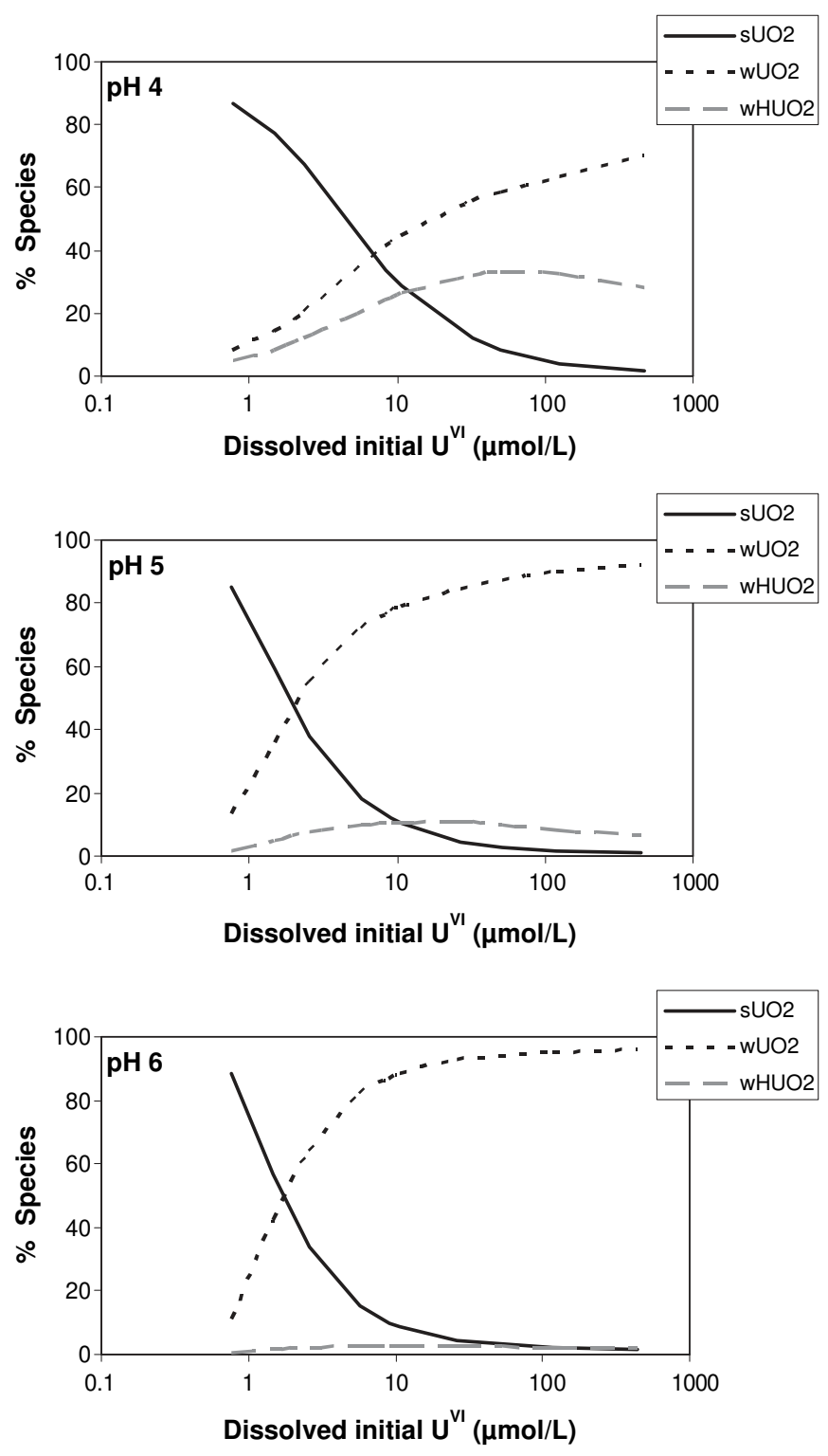

Fig. 9. Predicted speciation of sorbed $\mathrm{U}^{\mathrm{VI}}$ onto birnessite. $\mathrm{sUO}_{2}, \mathrm{wUO}_{2}$ and $\mathrm{wHUO}_{2}$ stand for the strong-affinity $\equiv \mathrm{Mn}_{\mathrm{s}} \mathrm{O}_{2} \mathrm{UO}_{2}$ specie and the weak-affinity $\equiv \mathrm{S}_{\mathrm{w}} \mathrm{O}_{3} \mathrm{UO}_{2}$ and $\equiv \mathrm{S}_{\mathrm{w}} \mathrm{O}_{3} \mathrm{HUO}_{2}^{+}$ species respectively. the experimental conditions of EXAFS samples $\mathrm{Bi} 5$ to $\mathrm{Bi} 8$ ( $\mathrm{pH} 5$ and 6 ), the predicted dominant specie is the corner-sharing $\equiv \mathrm{S}_{\mathrm{w}} \mathrm{O}_{3} \mathrm{UO}_{2}$ specie, reliable to the disappearance of the Mn neighbors in the EXAFS spectra. These results emphasize the influence of the dissolved $\mathrm{U}^{\mathrm{VI}}$ concentration on the surface sites prevailing in U uptake. Fig. 9 shows that the strong-affinity sites might be undetectable in experiments conducted with high $\mathrm{U}^{\mathrm{VI}}$ concentrations, which could therefore be irrelevant to natural uncontaminated soil or aquifer environments.

The strong-affinity site density was determined to be equal to 0.013 sites $/ \mathrm{nm}^{2}$, and represents $0.8 \%$ of the total site density for $\mathrm{U}^{\mathrm{VI}}$ sorption. This value is lower than the density of strong-affinity sites modeled for ferrihydrite surface (Dzombak and Morel, 1990; Waite et al., 1994; Gustafsson et al., 2009), however counterbalanced by a higher complexation constant. If these sites indeed correspond to the edge-sites assessed in Fig. 7, the almost-perfect steric fit between the $\mathrm{O}_{\mathrm{eq}}-\mathrm{O}_{\mathrm{eq}}$ distance of the uranyl moiety ( $2.73 \AA$ ) and the length of some unshared-edges in Mn octahedra $(2.76 \AA)$ might account for this high complexation constant. For comparison, the unshared-edge lengths in Fe octahedra are slightly longer (2.93-3.02 Å, Manceau et al., 1992a). With an external surface area equal to $14 \mathrm{~m}^{2} / \mathrm{g}$, the optimized density for these strong-affinity sites actually corresponds to $1.87 \times 10^{17}$ sites/g. Assuming that these sites are restricted to edge surface only (instead of covering the total external surface), the expression of the site density relative to the total external surface is actually inappropriate because the proportion of edge surface relative to the external surface changes with the size of the particles. The expression of the density relative to the particle edge surface would be more suitable. Unfortunately, this latter expression would be difficult to achieve because edge surface determination is particularly challenging. At this stage, only a rough calculation can be done, allowing to verify that the reported strong-affinity site density is compatible with the crystallographic structure of birnessite. For a $2 \times 2 \times 0.05 \mu \mathrm{m}$ particle size (corresponding to a theoretical external surface equal to the measured $14 \mathrm{~m}^{2} / \mathrm{g}$ with about 70 stacked layers), theoretical edge surface represents $2 \%$ of the external surface. This value leads to a site density equal to 0.18 sites/nm along the particle layer edges, corresponding to one strong-affinity site every $20 \mathrm{Mn}$ octahedra. Due to the nano-size of $\delta-\mathrm{MnO}_{2}$ particles (Grangeon et al., 2012), a significant increase of the edge surface proportion relative to the external BET surface area is expected in these oxides (Villalobos et al., 2005). The density of strongaffinity sites relative to external BET surface area is therefore expected to increase. The variation of this latter might account for the different $\mathrm{pH}$ values at which a change in the $\mathrm{U}^{\mathrm{VI}}$ surface coordination was observed on birnessite (this study) or $\delta-\mathrm{MnO}_{2}$ (Wang et al., 2013) i.e. change of coordination from bidentate edge-sharing to bidentate corner-sharing and/or monodentate complexation between $\mathrm{pH} 5$ and 6 on birnessite and above $\mathrm{pH} 7$ on $\delta-\mathrm{MnO}_{2}$. The augmentation of strongaffinity site density would indeed expand the range of influence of these sites.

The validation of this model was achieved by modeling the influence of the $\mathrm{S} / \mathrm{L}$ ratio (mass of solid/volume of solution). The good agreement between the concentration of $\mathrm{U}^{\mathrm{VI}}$ predicted to be sorbed onto birnessite for various $\mathrm{S} / \mathrm{L}$ ratios and the measured values is shown in Fig. 4. The shape of the modeled curve (sorbed $\mathrm{U}^{\mathrm{VI}} \mathrm{Vs}$. S/L ratio) is strongly influenced by the competition between $\mathrm{Mn}$ and $\mathrm{U}^{\mathrm{VI}}$ for sorption sites. Indeed, small variations of the Mn concentration in the initial solution tend to produce large variations in the modeled $\mathrm{U}^{\mathrm{VI}}$ sorption. The unexpected increase of $\mathrm{U}^{\mathrm{VI}}$ sorption for high $\mathrm{S} / \mathrm{L}$ ratios is clearly linked to the fact that dissolved Mn concentrations do not show a linear correlation with $\mathrm{S} / \mathrm{L}$ ratio, but instead tend to reach a plateau for high $\mathrm{S} / \mathrm{L}$ ratios due to solubility equilibrium. Consequently, the stagnation of the dissolved Mn concentration above $\mathrm{S} / \mathrm{L}$ ratio $\sim 3 \mathrm{~g} / \mathrm{L}$ results in a more negative surface charge and a reduced competition between $\mathrm{U}^{\mathrm{VI}}$ and $\mathrm{Mn}$ to the sorption sites, both mechanisms favoring $\mathrm{U}^{\mathrm{VI}}$ sorption. This behavior implies a strong influence of the $\mathrm{S} / \mathrm{L}$ ratio on $\mathrm{U}^{\mathrm{VI}}$-birnessite interaction, contrasting with the sorption of $\mathrm{U}^{\mathrm{VI}}$ onto iron oxides and silicates (McKinley and Jenne, 1991; Payne et al., 1998). 


\subsection{Comparative $U^{V I}$ affinity for birnessite and other minerals}

The control of $\mathrm{U}^{\mathrm{VI}}$ mobility in various surface environments is dominated by few types of geological material: mostly clays, zeolites and oxides. Among these latter, Fe-oxides and Mn-oxides are often intergrown in soils, lake sediments or marine nodules (Burns and Burns, 1979; Palumbo et al., 2001) and the partitioning of scavenged metals between the two phases remains difficult to assess. Nevertheless, O'Reilly and Hochella (2003) or Hochella et al. (2005) for instance successfully demonstrated that birnessite takes up much more $\mathrm{Pb}$ than the associated ferrihydrite. The partitioning between Mn oxides and other minerals with high sorption capacity can also be addressed, since it has been shown that $\mathrm{Pu}, \mathrm{Ba}, \mathrm{Ni}, \mathrm{Pb}$ and $\mathrm{Ce}$ can be preferentially bound to birnessite rather than to clays, iron oxides or zeolites, despite the marginal amount of birnessite ( $\sim$ \% or less) in the analyzed tuffs (Duff et al., 2001; Vaniman et al., 2002). This partitioning is especially relevant with respect to nuclear-waste field because alteration of the nuclear glasses produces, besides silicate colloids, some birnessite-type colloids which could play a major role in radionuclide migration (Abrajano et al., 1990; Buck and Bates, 1999). Therefore, a comparison of the adsorption capacities of these various minerals could shed some light on the primary control of $\mathrm{U}^{\mathrm{VI}}$ migration in natural environments. The surface complexation model developed in this study was used to predict the amount of $\mathrm{U}^{\mathrm{VI}}$ sorbed onto birnessite for some experimental conditions similar to several previous studies in which $\mathrm{U}^{\mathrm{VI}}$ sorption onto clays, zeolites or iron oxides was reported. The results of the model (onto H-birnessite) along with the measured $\mathrm{U}^{\mathrm{VI}}$ sorption onto the other minerals are reported in Table 4 . Comparison of the $\mathrm{U}^{\mathrm{VI}}$ affinity for these various sorbents was made using a distribution coefficient $\mathrm{Kd}\left(\mathrm{Kd}=\frac{[\mathrm{U}]_{\text {sorbed }}(\mathrm{mol} / \mathrm{g})}{[\mathrm{U}]_{\text {solution }}(\mathrm{mol} / \mathrm{ml})}\right)$, as well as a distribution coefficient relative to BET specific surface area $\left(\frac{\mathrm{Kd}}{\mathrm{Sspec}}\right)$. The comparison was limited to conditions close to the ones used for the establishment of our model, i.e.: $0.1 \mathrm{M}$ ionic strength, $\mathrm{pH}$ range of $4-6$ and $\mathrm{S} / \mathrm{L}$ ratio range of $0.1-3 \mathrm{~g} / \mathrm{L}$. These results demonstrate that the predicted Kds for birnessite are significantly higher than the measured values for montmorillonite and zeolitic clinoptilolite, whereas they are similar or lower than iron oxide $\mathrm{Kds}$, depending on the oxide crystallinity. However, when the surface area is taken into account ( $\mathrm{Kd} / \mathrm{S}_{\text {spec }}$ values), the affinity of $\mathrm{U}^{\mathrm{VI}}$ for birnessite per surface unit turns out to be comparable to its affinity to iron oxides. It should be noted that the surface area of the ferrihydrite samples from Waite et al. (1994), was not measured, but a value of $600 \mathrm{~m}^{2} / \mathrm{g}$ was assumed by the authors and used in the calculation of $\mathrm{Kd} / \mathrm{S}_{\text {spec }}$. This surface could be overestimated, yielding particularly low $\mathrm{Kd} / \mathrm{S}_{\text {spec }}$ values. However, even with a one-order-lower surface area $\left(60 \mathrm{~m}^{2} / \mathrm{g}\right.$ ), the $\mathrm{Kd} / \mathrm{S}_{\text {spec }}$ values for these samples would remain similar to that of birnessite. The highest modeled $\mathrm{Kd} / \mathrm{S}_{\mathrm{spec}}$ value relative to iron oxides arises for diluted $\mathrm{U}^{\mathrm{VI}}$ solution $(0.01 \mu \mathrm{mol} / \mathrm{L}$, ferrihydrite). This difference may be due to the proposed highly reactive external Mn octahedra sites (Fig. 7), showing a higher affinity for $U^{\mathrm{VI}}$ than the strong-affinity sites at the Fe-oxide surface, albeit predominant only for low $\mathrm{U}^{\mathrm{VI}}$ concentrations (Fig. 9). This is a very significant observation as this experimental "diluted" $\mathrm{U}^{\mathrm{VI}}$ concentration is the most relevant to natural, uncontaminated environments (for instance the average $\mathrm{U}^{\mathrm{VI}}$ concentration in open oceans or worldwide-rivers ranges from 0.004 to $0.02 \mu \mathrm{mol} / \mathrm{L}$ (Cochran, 1992)). It indicates that hexagonal birnessite could play a more significant role in natural environments than what has been suggested by the present comparison between experimental studies which are mostly carried out with high $\mathrm{U}^{\mathrm{VI}}$ concentration for various technical requirements. These Kd estimates reveal that in low$\mathrm{pH}$ environments (such as partially wetted soils or acidic lake sediments), hexagonal birnessite is able to sorb $U^{\mathrm{VI}}$ as much as Fe oxides, and this mineral, hence, could exert a significant control on $\mathrm{U}^{\mathrm{VI}}$ mobility. In higher $\mathrm{pH}$ environments (such as oceans), both birnessite structure and $\mathrm{U}^{\mathrm{VI}}$ speciation significantly change, requiring further work to pre$\operatorname{dict} \mathrm{U}^{\mathrm{VI}}$-birnessite interaction.

\section{Conclusion}

This study demonstrates the strong affinity of uranyl ions with the hexagonal birnessite surface. The sorption experiments and EXAFS measurements allow proposing a structural model of uranyl sorption onto the birnessite surface, in which two energetically different sites are involved. At low $\mathrm{pH}(\leq 5)$ a bidentate edge-sharing complex with external Mn octahedra can be inferred, whereas bidentate cornersharing and/or monodentate complexation above layer vacancies would most likely describe EXAFS features of higher $\mathrm{pH}$ samples ( $\mathrm{pH}$ 6). Based on this structural model, the proposed surface complexation model involves both weak-affinity and strong-affinity sites for $\mathrm{U}^{\mathrm{VI}}$ sorption. This model was able to reproduce not only the measured isotherms from $\mathrm{pH} 3$ to 5 , but also the unexpected increase of $\mathrm{U}^{\mathrm{VI}}$ sorption for high $\mathrm{S} / \mathrm{L}$ ratios. This latter was explained by a competition between $\mathrm{U}^{\mathrm{VI}}$ and dissolved Mn ions for the sorption sites.

The affinity of $\mathrm{U}^{\mathrm{VI}}$ for $\mathrm{Mn}$ oxides relative to various minerals with high sorption capacity was addressed by comparing the modeled sorption of $\mathrm{U}^{\mathrm{VI}}$ onto H-birnessite with previously reported $\mathrm{U}^{\mathrm{VI}}$ sorption onto clays, zeolites or iron oxides. The results show that, in low-pH environments (such as soils), the sorption of uranyl ions onto birnessite largely exceeds the sorption observed on montmorillonite or zeolite, and turns

\section{Table 4}

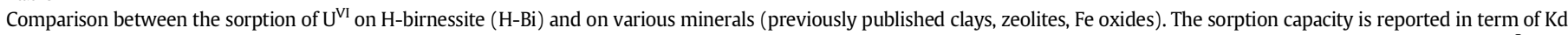

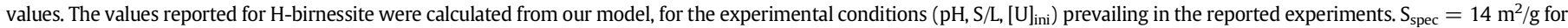
H-birnessite.

\begin{tabular}{|c|c|c|c|c|c|c|c|c|c|}
\hline \multirow[t]{2}{*}{ Mineral } & \multirow[t]{2}{*}{$\mathrm{pH}$} & \multirow{2}{*}{$\frac{\mathrm{S} / \mathrm{L}}{\mathrm{g} / \mathrm{L}}$} & \multirow{2}{*}{$\frac{\mathrm{S}_{\text {spec }}}{\mathrm{m}^{2} / \mathrm{g}}$} & \multirow{2}{*}{$\frac{[\mathrm{U}]_{\text {initial }}}{(\mu \mathrm{mol} / \mathrm{L})}$} & \multirow{2}{*}{$\frac{\mathrm{Kd} \text { minerals }}{\mathrm{mL} / \mathrm{g}}$} & \multirow{2}{*}{$\frac{\mathrm{Kd}(\text { model) } \mathrm{H}-\mathrm{Bi}}{\mathrm{mL} / \mathrm{g}}$} & \multirow{2}{*}{$\frac{\frac{\mathrm{Kd}_{\min }}{\mathrm{S}_{\text {spec }}}}{\mathrm{mL} / \mathrm{m}^{2}}$} & \multirow{2}{*}{$\frac{\frac{\mathrm{Kd}_{\mathrm{H}-\mathrm{Bi}}}{\mathrm{S}_{\mathrm{spec}}}}{\mathrm{mL} / \mathrm{m}^{2}}$} & \multirow[t]{2}{*}{ Data source } \\
\hline & & & & & & & & & \\
\hline Montmorillonite M1 & 4 & 3.2 & 97 & 0.24 & 469 & 2717 & 5 & 194 & [1] \\
\hline Montmorillonite M2 & 4 & 0.27 & 97 & 0.2 & 412 & 903 & 4 & 64 & [1] \\
\hline Clinoptilolite C1 & 4 & 2 & 10 & 0.21 & 26 & 1319 & 3 & 94 & [1] \\
\hline Hematite & 4.55 & 0.2 & 46 & 12.3 & 1100 & 297 & 24 & 21 & {$[2]$} \\
\hline Goethite & 4 & 1 & 45 & 10 & 667 & 91 & 15 & 6.5 & [3] \\
\hline $\mathrm{Fe}(\mathrm{OH})_{3} \mathrm{am}$ & 4 & 1 & 306 & 10 & 3000 & 91 & 10 & 6.5 & [3] \\
\hline Hematite & 4 & 1 & 3.1 & 10 & 20 & 91 & 7 & 6.5 & [3] \\
\hline Hematite & 5 & 1 & 3.1 & 10 & 667 & 633 & 215 & 45 & [3] \\
\hline Ferrihydrite & 4 & 1.76 & $600(60)$ & 1 & 1326 & 509 & $2(20)$ & 36 & {$[4]$} \\
\hline Ferrihydrite & 3.6 & 1.76 & $600(60)$ & 1 & 411 & 218 & $0.7(7)$ & 15 & [4] \\
\hline Ferrihydrite & 4 & 0.08 & $600(60)$ & 1 & 3125 & 433 & $5(52)$ & 31 & [4] \\
\hline Ferrihydrite & 4 & 0.08 & $600(60)$ & 0.01 & 5357 & 3000 & $9(89)$ & 214 & [4] \\
\hline
\end{tabular}

[1]: Pabalan et al. (1998); [2]: Bargar et al. (2000a); [3]: Hsi and Langmuir (1985); [4]: Waite et al. (1994).

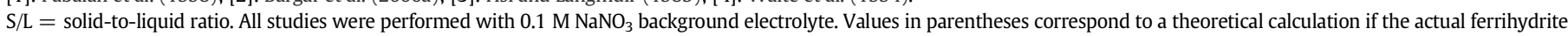
surface area is one order lower than the $600 \mathrm{~m}^{2} / \mathrm{g}$ value assumed by Waite et al. (1994) (see Section 4.3 for explanation). 
out to be comparable to iron oxides. Our model even suggests that sorption onto birnessite exceeds that onto ferrihydrite for the most diluted $\mathrm{U}^{\mathrm{VI}}$ concentration, i.e. the most relevant concentration to natural, uncontaminated environments. The proposed highly reactive edge sites, which show a much higher affinity for $U^{\mathrm{VI}}$ than the high-affinity sites at the Fe-oxides surface, might explain such enhanced sorption. It therefore suggests that experimental studies carried out with dissolved $\mathrm{U}^{\mathrm{V}}$ concentrations significantly higher than natural aqueous $\mathrm{U}^{\mathrm{VI}}$ concentrations could underestimate the role of birnessite in natural environments, and emphasizes the potential role of phyllomanganates to the control of uranyl mobility in post-oxic acidic environments.

\section{Acknowledgments}

This research was funded by the ACI "Eau et Environnement" CNRS program. We acknowledge the European Synchrotron Radiation Facility (Grenoble) for provision of synchrotron radiation facilities and we would like to thank the ROBL staff for assistance. We are especially grateful to Alain Manceau (ISTerre, France) for its initiation to the "birnessite world", and his improvement of the manuscript. The authors acknowledge D. Millon, for the atomic absorption analyses, J. Samuel and R. Boutin for ICP analyses, F. Hubert and J.L. Cezard for XRD acquisition and G. Morvan for SEM imaging, as well as M. Lanson (ISTerre, Grenoble) for its introduction to the birnessite synthesis. We would like to thank the editor, Jeremy Fein, and two anonymous reviewers for their comments which helped to improve this manuscript. This research is an EOST contribution.

\section{Appendix A. Supplementary data}

Supplementary data to this article can be found online at http://dx. doi.org/10.1016/j.chemgeo.2014.02.025.

\section{References}

Abrajano, T.A., Bates, J.K., Bradley, J.P., Woodland, A.B., Bourcier, W.L., 1990. Secondary phase formation during nuclear waste glass dissolution. Clay Clay Miner. 38 537-548.

Al-Attar, L., Dyer, A., 2002. Sorption behaviour of uranium on birnessite, a layered manganese oxide. J. Mater. Chem. 12, 1381-1386.

Ames, L.L., McGarrah, J.E., Walker, B.A., 1983. Sorption of trace constituents from aqueous solutions onto secondary minerals. I. Uranium. Clays Clay Minerals 31, 321-334.

Andersson, P.S., Wasserburg, G.J., Chen, J.H., Papanastassiou, D.A., Ingri, J., $1995 .{ }^{234} \mathrm{U}-{ }^{238} \mathrm{U}$ and ${ }^{232} \mathrm{Th}-{ }^{230} \mathrm{Th}$ in the Baltic Sea and in river water. Earth Planet. Sci. Lett. 130, 217-234.

Ankudinov, A., Rehr, J.J., 2000. Theory of solid state contributions to the x-ray elastic scattering amplitude. Phys. Rev. B 62, 2437-2445.

Appelo, C.A.J., Postma, D., 1999. A consistent model for surface complexation on birnessite $\left(\delta-\mathrm{MnO}_{2}\right)$ and its application to a column experiment. Geochim. Cosmochim. Acta 63, 3039-3048.

Aubert, D., Probst, A., Stille, P., 2004. Distribution and origin of major and trace elements (particularly REE, $U$ and Th) into labile and residual phases in an acid soil profile (Vosges Mountains, France). Appl. Geochem. 19, 899-916.

Axe, L., Tyson, T., Trivedi, P., Morrison, T., 2000. Local structure analysis of strontium sorption by hydrous manganese oxide. J. Colloid Interface Sci. 224, 408-416.

Balistrieri, L.S., Murray, J.W., 1982. The surface chemistry of $\delta \mathrm{MnO}_{2}$ in major ion seawater. Geochim. Cosmochim. Acta 46, 1041-1052.

Bargar, J.R., Reitmeyer, R., Lenhart, J.J., Davis, J.A., 2000a. Characterization of U(VI)carbonato ternary complexes on hematite: EXAFS and electrophoretic mobility measurements. Geochim. Cosmochim. Acta 64, 2737-2749.

Bargar, J.R., Tebo, B., Villinski, J.E., 2000b. In situ characterization of Mn(II) oxidation by spores of the marine Bacillus sp. strain SG-1. Geochim. Cosmochim. Acta 64, $2775-2778$.

Bargar, J.R., Tebo, B., Bergmann, U., Webb, S.M., Glatzel, P., Chiu, V.Q., Villalobos, M., 2005. Biotic and abiotic products of $\mathrm{Mn}$ (II) oxidation by spores of the marine Bacillus $s p$ strain SG-1. Am. Mineral. 90, 143-154.

Bargar, J.R., Fuller, C.C., Marcus, M.A., Brearley, A.J., De la Rosa, M.P., Webb, S.M., Caldwell, W.A., 2009. Structural characterization of terrestrial microbial Mn oxides from Pinal Creek, AZ. Geochim. Cosmochim. Acta 73, 889-910.

Bodeï, S., Manceau, A., Geoffroy, N., Baronnet, A., Buatier, M., 2007. Formation of todorokite from vernadite in Ni-rich hemipelagic sediments. Geochim. Cosmochim. Acta 71, 5698-5716.

Bourdon, B., Henderson, G.M., Lundstrom, C.C., Turner, S.P., 2003. Uranium-series geochemistry. Reviews in mineralogy and geochemistry, 52 . The mineralogical society of America, Washington.
Brennecka, G.A., Wasylenki, L.E., Bargar, J.R., Weyer, S., Anbar, A.D., 2011. Uranium isotope fractionation during adsorption to Mn-oxyhydroxides. Environ. Sci. Technol. 45, $1370-1375$

Buck, E.C., Bates, J.K., 1999. Microanalysis of colloids and suspended particles from nuclear waste glass alteration. Appl. Geochem. 14, 635-653.

Burns, R.G., Burns, V.M., 1979. Manganese Oxides. In: Burns, R.G. (Ed.), Reviews in Mineralogy and Geochemistry: Marine minerals, 6. The mineralogical society of America, Washington, pp. 1-46.

Burns, P.C., Ewing, R.C., Hawthorne, F.C., 1997. The crystal chemistry of hexavalent uranium: polyhedral geometries, bond-valence parameters, and polymerization of polyhedra. Can. Mineral. 35, 1551-1570.

Catalano, J., Brown, G.E.J., 2005. Uranyl adsorption onto montmorillonite: evaluation of binding sites and carbonates complexation. Geochim. Cosmochim. Acta 69, 2995-3005.

Chisholm-Brause, C., Berg, J.M., Matzner, R.A., Morris, D.J., 2001. Uranium(VI) sorption complexes on montmorillonite as a function of solution chemistry. J. Colloid Interface Sci. 233, 38-49.

Chukhrov, F.V., Sakharov, B.A., Gorshkov, A., Drits, V.A., Dikov, Y.P., 1985. Crystal structure of birnessite from the Pacific Ocean. Int. Geol. Rev. 27, 1082-1088.

Cochran, J.K., 1992. The Oceanic Chemistry of the Uranium- and Thorium-Series Nuclides. In: Ivanovich, M., Harmon, R.S. (Eds.), Uranium-series disequilibrium. Oxford University Press, New York, pp. 334-395.

Coda, A., Giusta, A.D., Tazzoli, V., 1981. The structure of synthetic andersonite, $\mathrm{Na}_{2} \mathrm{Ca}$ $\left[\mathrm{UO}_{2}\left(\mathrm{CO}_{3}\right) 3\right] . \mathrm{xH} 2 \mathrm{O}(\mathrm{x} \sim 5.6)$. Acta Crystallogr. B 37, 1496-1500.

Crerar, D.A., Barnes, H.L., 1974. Deposition of deep-sea manganese nodules. Geochim. Cosmochim. Acta 38, 279-300.

Dixon, J.B., Skinner, H.C.W., 1992. Manganese Minerals in Surface Environments. In: Skinner, H.C.W., Fitzpatrick, R.W. (Eds.), Biomineralization processes of iron and manganese. Modern and Ancient Environments. Catena Verlag, Cremlingen, Germany, pp. 31-50.

Doherty, J., 2004. PEST Model-Independent Parameter Estimation, User Manual. 5th ed. Watermark Numerical Computing, Corinda, Australia.

Drits, V.A., Silvester, E., Gorshkov, A., Manceau, A., 1997. The structure of synthetic monoclinic Na-rich birnessite and hexagonal birnessite. Part 1. Results from X-ray diffraction and selected area electron diffraction. Am. Mineral. 82, 946-961.

Duff, M.C., Hunter, D.B., Triay, I.R., Bertsch, P.M., Kitten, J., Vaniman, D., 2001. Comparison of two micro-analytical methods for detecting the spatial distribution of sorbed Pu on geological materials. J. Contam. Hydrol. 47, 211-218.

Dzombak, D.A., Morel, F.M.M., 1990. Surface Complexation Modelling: Hydrous Ferric Oxide. Wiley-Interscience, New York.

Evans, H.T., 1963. Uranyl ion coordination. Science. 141, 154-158.

Fox, P.M., Davis, J.A., Zachara, J.M., 2006. The effect of calcium on aqueous uranium(VI) speciation and adsorption to ferrihydrite and quartz. Geochim. Cosmochim. Acta 70, 1379-1387.

Fredrickson, J.K., Zachara, J.M., Kennedy, D., Liu, C., Duff, M.C., Hunter, D.B., Dohnalkova, A., 2002. Influence of Mn oxides on the reduction of uranium(VI) by the metal-reducing bacterium Shewanella putrefaciens. Geochim. Cosmochim. Acta 66, 3247-3262.

Friedl, G., Wehrli, B., Manceau, A., 1997. Solid phases in the cycling of manganese in eutrophic lakes: new insights from EXAFS spectroscopy. Geochim. Cosmochim. Acta 61, 275-290.

Giovanoli, R., Stähli, E., Feitknecht, W., 1970. Uber Oxidhyroxide des vierwertigen Mangans mit Schichtengitter.1 Mitteilung: Natrium-Mangan (II, III) Manganat(IV). Helv. Chim. Acta. 53, 454-464.

Grangeon, S., Manceau, A., Guilhermet, J., Gaillot, A.C., Lanson, M., Lanson, B., 2012. Zn sorption modifies dynamically the layer and interlayer structure of vernadite. Geochim. Cosmochim. Acta 85, 302-313.

Guillaumont, R, Fanghänel, T, Neck, V, Fuger, J. Palmer, D., Grenthe, I., Rand, M., 2003. Update on the chemical thermodynamics of uranium, neptunium, plutonium, americium and technetium. Chemical thermodynamics, 5. Elsevier B.V, Amsterdam.

Gustafsson, J.P., Dässman, E., Bäckström, M., 2009. Towards a consistent geochemical model for prediction of uranium(VI) removal from groundwater by ferrihydrite. Appl. Geochem. 24, 454-462.

Herczeg, A., Simpson, J., Anderson, R., Trier, R., Mathieu, G., Deck, B., 1988. Uranium and radium mobility in groundwaters and brines within the Delaware basin, Southeastern New Mexico, USA. Chem. Geol. 72, 181-196.

Hochella, M.F.J., Kasama, T., Putnis, A., Putnis, C., Moore, J.N., 2005. Environmentally important, poorly crystalline $\mathrm{Fe} / \mathrm{Mn}$ hydrous oxides: ferrihydrite and a possibly new vernadite-like mineral from the Clark Fork River Superfund complex. Am. Mineral. $90,718-724$

Hsi, C.K.D., Langmuir, D., 1985. Adsorption of uranyl onto ferric oxyhydroxides: application of the surface complexation site-binding model. Geochim. Cosmochim. Acta 49, 1931-1941.

Hudson, E.A., Allen, P.G., Terminello, L.J., 1996. Polarized X-ray absorption spectroscopy of the uranyl ion: comparison of experiment and theory. Phys. Rev. B 54, 156-165.

Hudson, E.A., Terminello, L.J., Viani, B.E., Denecke, M.A., Reich, T., Allen, P.G., Bucher, J.J. Shuh, D.K., Edelstein, N.M., 1999. The structure of $\mathrm{U}^{6+}$ sorption complexes on vermiculite and hydrobiotite. Clays Clay Minerals 47, 439-457.

Isaure, M.-P. Manceau, A., Geoffroy, N., Laboudige, A., Tamura, N., Marcus, M.A. 2005. Zinc mobility and speciation in soil covered by contaminated dredged sediment using micrometer-scale and bulk-averaging X-ray fluorescence, absorption and diffraction techniques. Geochim. Cosmochim. Acta 69, 1173-1198.

Ivanovich, M., Harmon, R.S., 1992. Uranium-Series Disequilibrium. Oxford University Press, New York.

Jürgensen, A., Widmeyer, J.R., Gordon, R.A., Bendell-Young, L.I., Moore, M.M., Crozier, E.D., 2004. The structure of the manganese oxide on the sheath of the bacterium Leptothrix discophora: an EXAFS study. Am. Mineral. 89, 1110-1118. 
Koschinsky, A., Hein, J.R., 2003. Uptake of elements from seawater by ferromanganese crusts: solid-phase associations and seawater speciation. Marine Geol. 198, 331-351.

Langmuir, D., 1978. Uranium solution-mineral equilibria at low temperature with applications to sedimentary ore deposits. Geochim. Cosmochim. Acta 42, 547-569.

Lanson, B., Drits, V.A., Silvester, E., Manceau, A., 2000. Structure of H-exchanged hexagonal birnessite and its mechanism of formation from Na-rich monoclinic buserite at low pH: new data from X-ray diffraction. Am. Mineral. 85, 826-835.

Lanson, B., Drits, V.A., Feng, Q., Manceau, A., 2002a. Structure of synthetic Na-birnessite: evidence for a triclinic one-layer unit cell. Am. Mineral. 87, 1662-1671.

Lanson, B., Drits, V.A., Gaillot, A.-C., Silvester, E., Plançon, A., Manceau, A., 2002b. Structure of heavy-metal sorbed birnessite: Part 1. Results from X-ray diffraction. Am. Mineral. 87, 1631-1645.

Lee, S.Y., Baik, M.H., Lee, Y.J., Lee, B.L., 2009. Adsorption of U(VI) ions on biotite from aqueous solutions. Appl. Clay Sci. 46, 255-259.

Li, X., Pan, G., Qin, Y., Hu, T., Wu, Z., Xie, Y., 2004. EXAFS studies on adsorption-desorption reversibility at manganese oxide-water interfaces II. Reversible adsorption of zinc on $\delta-\mathrm{MnO}_{2}$. J. Colloid Interface Sci. 271, 35-40.

Madden, A.S., Hochella, M.F., Luxton, T.P., 2006. Insights for size-dependent reactivity of hematite nanomineral surfaces through $\mathrm{Cu}^{2+}$ sorption. Geochim. Cosmochim. Acta 70, 4095-4104.

Manceau, A., Charlet, L., Boisset, M.C., Didier, B., Spadini, L., 1992a. Sorption and speciation of heavy metals on hydrous Fe and Mn oxides. From microscopic to macroscopic. Appl. Clay Sci. 7, 201-223.

Manceau, A., Gorshkov, A., Drits, V.A., 1992b. Structural chemistry of Mn, Fe, Co and Ni in manganese hydrous oxides: part II. Information from EXAFS spectroscopy and electron and X-ray diffraction. Am. Mineral. 77, 1144-1157.

Manceau, A., Drits, V.A., Silvester, E., Bartoli, C., Lanson, B., 1997. Structural mechanism of Co(II) oxidation by the phyllomanganate buserite. Am. Mineral. 82, 1150-1175.

Manceau, A., Lanson, B., Drits, V.A., 2002a. Structure of heavy-metal sorbed birnessite: Part 3. Results from powder and polarized extended x-ray absorption fine structure spectroscopy. Geochim. Cosmochim. Acta 66, 2639-2663.

Manceau, A., Tamura, N., Marcus, M.A., MacDowell, A.A., Celestre, R.S., Sublett, R.E., Sposito, G., Padmore, H.A., 2002b. Deciphering Ni sequestration in soil ferromanganese nodules by combining X-ray fluorescence, absorption, and diffraction at micrometer scales of resolution. Am. Mineral. 87, 1494-1499.

Manceau, A., Tamura, N., Celestre, R.S., MacDowell, A.A., Geoffroy, N., Sposito, G., Padmore, H.A., 2003. Molecular-scale speciation of $\mathrm{Zn}$ and $\mathrm{Ni}$ in soil ferromanganese nodules from loess soils of the Mississippi basin. Environ. Sci. Technol. 37, 75-80.

Manceau, A., Tommaseo, C., Rihs, S., Geoffroy, N., Chateigner, D., Schlegel, M., Tisserand, D. Marcus, M.A., Tamura, N., Chen, Z.S., 2005. Natural speciation of Mn, Ni, and Zn at the micrometer scale in a clayey paddy soil using X-ray fluorescence, absorption, and diffraction. Geochim. Cosmochim. Acta 69, 4007-4034.

Matocha, C., Elzinga, E., Sparks, D., 2001. Reactivity of $\mathrm{Pb}$ (II) at the Mn(III, IV) (oxyhydr) oxide-water interface. Environ. Sci. Technol. 35, 2967-2972.

McKinley, J.P., Jenne, E.A., 1991. Experimental investigation and review of the "solids concentration" effect in adsorption studies. Environ. Sci. Technol. 25, 2082-2087.

Metz, V., Raanan, H., Piper, H., Bosbach, D., Ganor, J., 2005. Towards the establishment of a reliable proxy for the reactive surface area of smectite. Geochim. Cosmochim. Acta 69, 2581-2591.

Montes-Hernandez, H., Rihs, S., 2006. A simplified method to estimate kinetic and thermodynamic parameters on the solid-liquid separation of pollutants. J. Colloid Interface Sci. 299, 49-55.

Müller, B., Granina, L., Schaller, T., Ulrich, A., Wehrli, B., 2002. P, As, Sb, Mo, and other elements in sedimentary Fe/Mn layers of lake Baikal. Environ. Sci. Technol. 36, 411-420.

Newville, M., Ravel, B., Haskel, D., Rehr, J.J., Stern, A., Yacoby, Y., 1995. Analysis of multiplescattering XAFS data using theoretical standards. Phys. B Condens. Matter 208-209, 154-156.

O'Reilly, S.E., Hochella, M.F.J., 2003. Lead sorption efficiencies of natural and synthetic Mn and Fe-oxides. Geochim. Cosmochim. Acta 67, 4471-4487.

Pabalan, R.T., Turner, D.R., Bertetti, F.P., Prikryl, J.D., 1998. Uranium ${ }^{\mathrm{VI}}$ Sorption onto Selected Mineral Surfaces: Key Geochemical Parameters. In: Jenne, E.A. (Ed.), Adsorption of Metals by Geomedia. Academic Press, New York, pp. 99-130.

Palumbo, B., Bellanca, A., Neri, R., Roe, M.J., 2001. Trace metal partitioning in Fe-Mn nodules from Sicilian soils, Italy. Chem. Geol. 173, 257-269.

Parkhurst, D.L., Appelo, C.A., 1999. User's Guide to PHREEQC (Version 2). A computer program for speciation, batch-reaction, one-dimensional transport, and inverse geochemical calculations. Report 99-4259.

Payne, T.E., Lumpkin, G.R., Waite, T.D., 1998. Uranium ${ }^{\mathrm{VI}}$ Adsorption on Model Minerals. In: Jenne, E.A. (Ed.), Adsorption of Metals by Geomedia. Academic Press, New York pp. 75-97.
Peacock, C., Sherman, D., 2007. Sorption of Ni by birnessite: equilibrium controls on $\mathrm{Ni}$ in seawater. Chem. Geol. 238, 94-106.

Post, J.E., 1999. Manganese oxide minerals: crystal structure and economic and environmental significance. Proc. Natl. Acad. Sci. U. S. A. 96, 3447-3454.

Post, J.E., Veblen, D.R., 1990. Crystal structure determinations of synthetic sodium, magnesium, and potassium birnessite using TEM and the Rietveld method. Am. Mineral. 75 477-489.

Powell, B., Duff, M.C., Kaplan, D., Fjeld, R., Newville, M., Hunter, D.B., Bertsch, P., Coates, J., Eng, P., Rivers, M., Serkiz, S., Sutton, S., Triay, I., Vaniman, D., 2006. Plutonium oxidation and subsequent reduction by Mn(IV) minerals in Yucca Mountain Tuff. Environ. Sci. Technol. 40, 3508-3514.

Ravel, B., Newville, M., 2005. Athena, Artemis, Hephaestus: data analysis for X-ray absorption spectroscopy using IFEFFIT. J. Synchrotron Radiat. 12, 537-541.

Reich, T., Moll, H., Arnold, T., Denecke, M.A., Henning, C., Geipel, G., Bernhard, G., Nitsche H., Allen, P.G., Bucher, J.J., Edelstein, N.M., Shuh, D.K., 1998. An EXAFS study of uranium (VI) sorption onto silica gel and ferrihydrite. J. Electron Spectrosc. Relat. Phenom. 96, 237-243.

Reich, T., Bernhard, G., Geipel, G., Funke, H., Hennig, C., Rossberg, A., Matz, W., Schell, N. Nitsche, H., 2000. The Rossendorf Beam Line ROBL - a dedicated experimental station for XAFS measurements of actinides and other radionuclides. Radiochim. Acta 88, 633-637.

Rossberg, A, Ulrich, KU, Weiss, S., Tsushima, S. Hiemstra, T, Scheinost, A, 2009. Identification of uranyl surface complexes on ferrihydrite: advanced EXAFS data analysis and CD-MUSIC modeling. Environ. Sci. Technol. 43, 1400-1406.

Sherman, D.M., Peacock, C.L., Hubbard, C.G., 2008. Surface complexation of U(VI) on goethite $(\alpha-\mathrm{FeOOH})$. Geochim. Cosmochim. Acta 72, 298-310.

Silvester, E., Manceau, A., Drits, V.A., 1997. Structure of synthetic monoclinic Na-rich birnessite and hexagonal birnessite. Part 2. Results from chemical studies and EXAFS spectroscopy. Am. Mineral. 82, 962-978.

Takahashi, Y., Manceau, A., Geoffroy, N., Marcus, M.A., Usui, A., 2007. Chemical and structural control of the partitioning of $\mathrm{Co}, \mathrm{Ce}$, and $\mathrm{Pb}$ in marine ferromanganese oxides. Geochim. Cosmochim. Acta 71, 984-1008.

Tebo, B., Bargar, J.R., Clement, B.G., Dick, G.J., Murray, K.J., Parker, D., Verity, R., Webb, S.M., 2004. Biogenic manganese oxides: properties and mechanisms of formation. Annu. Rev. Earth Planet. Sci. 32, 287-328.

Tipping, E., Thompson, D.W., Davidson, W., 1984. Oxidation products of Mn(II) in lake waters. Chem. Geol. 44, 359-383.

Toner, B., Manceau, A., Webb, S.M., Sposito, G., 2006. Zinc sorption to biogenic hexagonalbirnessite particles within a hydrated bacterial biofilm. Geochim. Cosmochim. Acta 70, 27-43.

Tonkin, J.W., Balistrieri, L.S., Murray, J.W., 2004. Modeling sorption of divalent metal cations on hydrous manganese oxide using the diffuse double layer model. Appl Geochem. 19, 29-53.

Tournassat, C., Charlet, L., Bosbach, D., Manceau, A., 2002. Arsenic(III) oxidation by birnessite and precipitation of manganese(II) arsenate. Environ. Sci. Technol. 36, 493-500.

Vaniman, D.T., Chipera, S.J., Bish, D.L., Duff, M.C., Hunter, D.B., 2002. Crystal chemistry of clay-Mn oxide association in soils, fractures and matrix of the Bandelier tuff, Pajarito Mesa, New Mexico. Geochim. Cosmochim. Acta 66, 1349-1374.

Villalobos, M., Toner, B., Bargar, J., Sposito, G., 2003. Characterization of the manganese oxide produced by pseudomonas putida strain MnB1. Geochim. Cosmochim. Acta 67, 2649-2662.

Villalobos, M., Bargar, J.R., Sposito, G., 2005. Mechanisms of Pb(II) sorption on a biogenic manganese oxide. Environ. Sci. Technol. 39, 569-576.

Villalobos, M., Lanson, B., Manceau, A., Toner, B., Sposito, G., 2006. Structural model for the biogenic Mn oxide produced by Pseudomonas putida. Am. Mineral. 91, 489-502.

Waite, T.D., Davis, J.A., Payne, T.E., Waychunas, G.A., Xu, N., 1994. Uranium(VI) adsorption to ferrihydrite: application of a surface complexation model. Geochim. Cosmochim. Acta 58, 5465-5478.

Wang, Z., Lee, S.W., Catalano, J.G., Lezama-Pacheco, J.S., Bargar, J.R., Tebo, B., Giammar, D.E 2013. Adsorption of uranium(VI) to manganese oxides: X-ray absorption spectroscopy and surface complexation modeling. Environ. Sci. Technol. 47, 850-858.

Webb, S.M., Fuller, C.C., Tebo, B., Bargar, J.R., 2006. Determination of uranyl incorporation into biogenic manganese oxides using X-ray absorption spectroscopy and scattering. Environ. Sci. Technol. 40, 771-777.

Zeng, H., Singh, A., Basak, S., Ulrich, K.U., Sahu, M., Biswas, P., Catalano, J., Giammar, D. 2009. Nanoscale size effects on uranium(VI) adsorption to hematite. Environ. Sci. Technol. 43, 1373-1378. 